\title{
Climate-related variability in abundance of mesozooplankton in the northern Gulf of Alaska 1998-2009
}

\author{
by \\ Leandra Sousa ${ }^{a^{* 1}}$ \\ Kenneth O. Coyle ${ }^{\text {a }}$ \\ Ronald P. Barry ${ }^{\mathrm{b}}$ \\ Thomas J. Weingartner ${ }^{\mathrm{a}}$ \\ Russell R. Hopcroft ${ }^{\text {a }}$
}

${ }^{\text {a }}$ School of Fisheries and Ocean Sciences, University of Alaska Fairbanks, P.O. Box 757220, Fairbanks, Alaska, 99775-7220, USA

${ }^{\mathrm{b}}$ Department of Mathematics and Statistics, University of Alaska Fairbanks, P.O. Box 756660, Fairbanks, Alaska, 99775-6660 USA

* Corresponding author's contact information: E-mail: leandra.sousa@ north-slope.org (L. Sousa); Tel.: +1 907852 0350; Address: Department of Wildlife Management, North Slope Borough, P.O. Box 69 Barrow, Alaska, 99723, USA

Submitted to Deep Sea Research Part II

\footnotetext{
${ }^{1}$ Permanent address: Department of Wildlife Management, North Slope Borough, P.O. Box 69 Barrow, Alaska, 99723, USA; Tel: +1 907852 0350; E-mail: leandra.sousa@north-slope.org
} 


\begin{abstract}
Significant changes in fisheries resources have occurred in the Gulf of Alaska (GOA) in the mid 1970s, with an increase in groundfish and a decrease in crab and shrimp populations. Increased fishing pressure and such events suggest that the GOA is susceptible to climate variation; however the mechanistic links between ecosystem change and climate remain unclear. At-sea surveys were undertaken during the month of May from 1998 to 2009 to collect data on zooplankton abundance and water mass properties in the northern GOA. Significant changes in temperature, salinity and zooplankton abundance were identified during this period. The euphausiid Thysanoessa inermis and the copepod Calanus marshallae had increased abundances in years when there was a strong phytoplankton spring bloom preceded by anomalously cold winters. The euphausiid Euphausia Pacifica and the copepods Pseudocalanus spp., Neocalanus plumchrus/flemingeri, and Oithona spp. were more resilient to relatively high mean water temperatures. High zooplankton abundances in years of substantial cross-shelf mixing suggest that iron and nutrient transport between the shelf and oceanic domains are essential for sustaining high zooplankton populations via phytoplankton blooms. The abundance of zooplankton in the northern GOA is highly influenced by advective processes and changes in temperature. Further understanding of biological and physical mechanisms that control the GOA ecosystem are of major importance to predict the response of zooplankton communities to environmental changes.
\end{abstract}


Keywords: Climate; Zooplankton; Abundance, Oceanography, Gulf of Alaska 


\section{Introduction}

The northern shelf of the Gulf of Alaska (GOA) is a rich and diverse ecosystem, which sustains a number of important fisheries resources such as crustaceans, salmon, halibut, pollock and sablefish (Ware and McFarlane, 1989; Weingartner et al., 2002; Willette et al., 2001). Mesozooplankton are a critical trophic link between these commercial target species and microplankton (both primary producers and microheterotrophs) (Armstrong et al., 2005; Dagg et al., 2006; Liu et al., 2008; Sigler et al., 2001), such that high zooplankton abundance may increase the probability of survival of juvenile salmon (Willette et al., 2001) and suppress the increase in biomass of microzooplankton (Strom et al., 2007). Therefore, it is important to better understand the variations in zooplankton abundance and their associations with physical changes in the marine environment.

The zooplankton community in the northern GOA is mainly composed of copepods, euphausiids, chaetognaths, pteropods, larvaceans and cnidarians (Coyle and Pinchuk, 2003). The biomass in the zooplankton community is usually dominated by large oceanic copepods, such as Neocalanus cristatus, $N$. plumchrus, $N$. flemingeri and Eucalanus bungii, which are responsible for the annual biomass peak during spring and early summer (Coyle and Pinchuk, 2003; Coyle and Pinchuk, 2005). This seasonal biomass peak is related to life cycle timing of these dominant copepod species, which over-winter in deep waters below the pycnocline and their nauplii migrate above the pycnocline in spring and early summer to feed and complete their somatic growth (Kobari and Ikeda, 2001a; Miller and Clemons, 1988; Tsuda et al., 1999). Subsequently, 
the rapid summer decline in biomass in surface waters occurs mainly because these four species migrate to diapause in deep waters (Coyle and Pinchuk, 2005; Kobari and Ikeda, 2001b; Tsuda et al., 2004). Conversely, smaller more neritic copepods, such as Metridia pacifica, Pseudocalanus spp. and Oithona spp., are the most populous species in the zooplankton community, which have their annual abundance peak in summer. Therefore, the biomass and abundance peaks in zooplankton species in the GOA are mainly represented by oceanic and neritic copepod species, respectively (Coyle and Pinchuk, 2003).

Zooplankton species may respond differently to changes in temperature and food concentration, and their abundance may also change as a result of vertical and cross-shelf mixing that may affect dispersal of organisms in the water column (Coyle and Pinchuk, 2005; Mackas and Coyle, 2005; Pinchuk et al., 2008). Species that are abundant in the upper mixed layer such as Neocalanus plumchrus and $N$. flemingeri are more likely to be advected onshore by Ekman transport, while species that are abundant below the mixed layer such as $N$. cristatus and E. bungii are less likely to be advected onshore by surface currents (Coyle and Pinchuk, 2005). Taxa that undergo diel vertical migration such as Metridia spp. and euphausiids will be influenced by Ekman transport at night and subsurface flow during the day. Mixing processes can influence the distribution of zooplankton species, such that oceanic species are advected into the coastal habitat and neritic species towards the slope (Coyle and Pinchuk 2005; Mackas and Coyle 2005; Pinchuk et al. 2008). These processes include seasonal changes in cyclonic winds and Ekman transport and interaction of currents with the complex coast and bathymetry that 
can generate eddies and meanders that enhance cross-shelf transport of water masses (Okkonen et al. 2003; Weingartner et al. 2005; Janout et al. 2009). The shelf ecosystem in the GOA undergoes shifts in crustacean and fin-fish populations. In the mid-1970s, salmon and ground fish populations increased, while crab and shrimp populations decreased, and these changes corresponded to a strong regime shift in 1976-77 (Anderson and Piatt, 1999; Francis and Hare, 1994; Mantua et al., 1997). Later in the 1980s, marine mammal and seabird populations also declined, while the ground fish populations continued to increase (Hatch and Sanger, 1992; Merrick et al., 1987; Springer, 1998). The mechanism linking oceanographic regime shifts to the response by fisheries populations remains unclear, but the link is likely to involve shifts in the abundance, biomass and species composition of primary producers and secondary consumers. Longterm observation programs may help identify vulnerable populations and their response to changes in the physical environment. This paper outlines the response of major mesozooplankton taxa to changes in the environment of the GOA shelf and investigates the following hypotheses: 1) Inter- annual variability in zooplankton abundance is influenced by changes in water mass properties, 2) zooplankton species in the GOA will respond differently to changes in water mass properties according to their distribution along the shelf (neritic and oceanic) and within the water column (mixed layer, below and within the pycnocline).

\section{Methods}




\subsection{Study area}

The northern GOA is a very dynamic environment, and has a complex bathymetry with many canyons, troughs and a deep shelf (Weingartner et al., 2005). During fall and winter, strong westward alongshore winds cause onshore Ekman transport and coastal downwelling. During spring and summer downwelling diminishes as winds relax (Stabeno et al., 2004; Weingartner et al., 2005). The main currents in this region are the Alaska Coastal Current (ACC), which flows westward within 20-50 km of the coast (Royer, 1982; Weingartner et al., 2005), and the Alaska Current seaward of the shelfbreak, which narrows and intensifies west of Kodiak Island to become the Alaskan Stream, a western boundary current of the Subarctic Gyre (Figure 1) (Reed, 1984; Reed and Stabeno 1989).

The study area was divided into three zones: the inner and middle shelves and the oceanic domain (Figure 2). Here the shelf is broad (160 km wide) and deep, with bottom depths exceeding $150 \mathrm{~m}$. Irregular bathymetry characterizes the shelf; water shoals from $250 \mathrm{~m}$ on the inner shelf to $150 \mathrm{~m}$ in the middle shelf before deepening again (Figure 2). The inner shelf is highly influenced by freshwater runoff, and in late spring and summer, high salinity oceanic waters penetrate the sub-surface waters of the inner and middle shelves, which have a mixture of neritic and oceanic waters (Coyle and Pinchuk, 2005). The oceanic domain has high salinity basin waters, and can be subject to mesoscale anticyclonic eddies propagating westward along the shelfbreak and slope (Janout et al. 2009; Okkonen et al., 2003). 
Surveys were conducted along the Seward line ( 220 km) during May from 19982009 (Figure 2) as part of the Global Ocean Ecosystems Dynamics (GLOBEC) Long Term Observation Program (LTOP) in the northern GOA, Rough weather precluded a complete coverage of the Seward line in 2008; hence, this survey year was not included in the analyses. Data from May were chosen for analysis because zooplankton biomass peaks during this month (Coyle and Pinchuk, 2003; Coyle and Pinchuk 2005) and because continued sampling in May has provided an uninterrupted time series from 1998 to 2009 .

\subsection{Data Collection}

From 1998 - 2004 large zooplankton and micronekton (Neocalanus cristatus, Eucalanus bungii, Calanus marshalae, Metridia spp., Neocalanus plumchrus, Neocalanus flemingeri, Thysanoessa inermis, Euphausia pacifica, Thysanoessa spinifera, Pterapods and Chaetognatha) were collected with a $1 \mathrm{~m}^{2}$ Multiple Opening/ Closing Net and Environmental Sampling System (MOCNESS) (Wiebe et al., 1976) with $500 \mu \mathrm{m}$ mesh nets. This was replaced with a Hydrobios Midi $\left(0.25 \mathrm{~m}^{2}\right)$ MultiNet of the same mesh size from 2005-2009. No significant difference in catches between MOCNESS and MultiNet have been identified in the upper $100 \mathrm{~m}$ of the water column (Skjodal et al. 2013), therefore the change between MOCNESS and MultiNet is not a source of bias in data presented in this study. Nets were fished at night and five oblique samples were collected in 20-m increments from $100 \mathrm{~m}$ depth to the surface. The small-bodied zooplankton (Pseudocalanus spp., Oithona spp., Acartia spp., calanoid nauplii and 
larvaceans) component was sampled with a 25-cm diameter CalVET system (CalCOFI Vertical Egg Tow; Smith et al. 1985) having 150- $\mu$ m mesh nets. Each net was equipped with General Oceanics flowmeters in the mouth of the nets to monitor volume filtered. The net was fished at daytime and vertically from $100 \mathrm{~m}$ depth to the surface. Zooplankton samples were taken at 13 stations spaced $18 \mathrm{~km}$ apart along the Seward line (Figure 2). Samples were preserved in a 10\% formalin seawater solution and stored for later analysis. All animals in the samples were sorted and identified to the lowest taxonomic category possible; abundance estimates were calculated following the methods of Coyle and Pinchuk (2005). Results in the present study were integrated for the upper $100 \mathrm{~m}$ of the water column. Coyle and Pinchuk (2005) describe in detail the zooplankton depth distribution in the northern GOA.

Conductivity-temperature-depth (CTD) profiles were collected from surface to bottom at $1 \mathrm{~m}$ increments using a Seabird model 911 Plus fitted with conductivity, temperature and fluorescence sensors (Weingartner et al., 2005). Nineteen stations at $\sim 8$ $\mathrm{km}$ intervals were sampled along the shelf and slope, and 3 stations at $\sim 18 \mathrm{~km}$ intervals were sampled off the shelfbreak (Figure 2). Mean temperature, salinity and sigma-t were calculated by averaging data from the upper $100 \mathrm{~m}$. Pycnocline depths were determined by calculating the depth of maximum vertical gradient in sigma-t through the water column. Average upper and lower temperatures, salinities and sigma-t were calculated above and below the pycnocline. In addition, the stratification parameter, the energy required to redistribute the water-column mass by complete vertical mixing $\left(\mathrm{J} \mathrm{m}^{-3}\right)$, was computed as in Simpson et al. (1977): 


$$
\bar{v}=\frac{1}{h} \int_{-h}^{0}(\rho-\bar{\rho}) g z d z, \quad \bar{\rho}=\frac{1}{h} \int_{-h}^{0} \rho d z \quad \text { (Equation 1) }
$$

where $z$ is the vertical coordinate (positive upwards), $h$ is the depth, $\rho$ is the density with mean $\bar{\rho}$, and $\bar{v}$ is the work which would be done in redistributing the mass in bringing about complete vertical mixing.

\subsection{Data analysis}

The data collected in this study were used to characterize inter-annual variations in zooplankton abundance and water mass properties and to identify the underlying relationship between mean zooplankton abundance and water mass properties during the period of 1998-2009, in the northern GOA.

\subsubsection{Inter-annual variation}

Analysis of variance (ANOVA) (Zar, 1999) was used to test the alternative hypothesis that mean zooplankton abundance, salinity, temperature, pycnocline depth and stratification parameter were different among years The most abundant taxonomic groups in our surveys were selected for the analysis. Copepodid stages IV to VI of the Neocalanus plumchrus-N. flemingeri species complex were routinely identified to species. Earlier stages were referred to as Neocalanus plumchrus-flemingeri. Metridia pacifica represented the majority of Metridia spp. while Metridia okhotensis were less abundant. Pseudocalanus spp.were not identified to species level. Species likely to occur in the northern Gulf of Alaska include P. minutus, $P$. moultani, $P$. newmani and $P$. 
mimus. Species previously identified from Shelikof Strait include all of the above except P. moultani (Siefert, 1994). Oithona similis represented the majority of Oithona spp. while Oithona spinirostris represented $<0.1 \%$. Only adult and occasionally stage V Acartia were identified to species. Earlier copepodids were identified as Acartia spp. The specimens identified to species were A. longiremis and A. hudsonica. Limicina helicina composed $90 \%$ of the Pterapods in the samples. Larvaceans were often damaged by the nets during collection; therefore it was not possible to identify them to the species level. Due to the reasons stated above the following taxonomic categories were used in this study: 1-Pseudocalanus spp.; 2-Oithona spp. 3-Acartia spp., 4-Metridia spp., 5Calanus marshallae, 6-Neocalanus plumchrus and Neocalanus flemingeri, 7-Neocalanus cristatus, 8-Eucalanus bungii, 9-Calanoid nauplii, 10-Euphausia pacifica, 11Thysanoessa inermis, 12-Thysanoessa spinifera, 13-Pteropoda, 14-Chaetognatha, 15Larvacea. Zooplankton analyses were performed using STATISTICA 6 software. Zooplankton abundance was power transformed (raised to the power of 0.15) to stabilize the variance and tests were considered significant at $p \leq 0.05$. Tukey's test was used to identify which years had significantly different mean zooplankton abundance. The sampling unit used for this analysis was a station/year combination, such that the annual values were obtained by computing the mean of all stations sampled in each year. ANOVA and Tukey's test were also used to test for the interannual differences in zooplankton abundance, salinity, temperature, pycnocline depth and stratification parameter among the inner, middle and offshore zones. The sampling unit used for this 
analysis was a zone/year combination, such that the annual values were obtained by computing the mean of all stations in each zone sampled in each year.

\subsubsection{Model development}

Generalized additive model regressions (GAM) (Hastie and Tibshirani, 1990; Wood, 2006) were used to investigate the relationship between zooplankton abundance and water mass properties. GAM is a non-parametric regression method, which allows the modeling of a curved relationship between the response and explanatory variables and can allow for non-normality in the errors. A GAM is comprised of a response variable, an additive predictor, and a link function that links the two components. A model with $p$ explanatory variables has the following form:

$$
g(\mu)=\alpha \sum_{j=1}^{p} f_{j}\left(x_{j}\right) \quad \text { (Equation 2) }
$$

Where $\mu$ is the mean of the response variable, $\alpha$ is a constant term, $f_{j}$ are the nonparametric smoothing functions of the explanatory variables $x_{j}$, and $g$ is the link function.

In this study the response (or dependent) variables in the GAMs were mean abundance of each zooplankton taxon per station. GAMs were run using the mgcv library in R, version 2.11.1 (Wood, 2004), with a gaussian family (normal distribution with an identity link function), and cubic regression splines as the smoothing function of predictor variables. For each taxon, a subset of predictor variables (water mass properties) that produced the best-fit models was selected using generalized cross validation (GCV) methods (Wood, 2006). Significance of the predictor variables was assessed by using Chi-square statistics calculated by R (R Development Core Team 
2009). In addition, partial regression plots showing the additive effect of each predictor variable on the abundance of each zooplankton taxa were examined for linearity, significance and positive and negative effect. Residuals from best-fit models were checked for the assumption of independence and identical distributions. The resulting best-fit models were used to indicate which predictor variables may have a significant effect on the abundance of each zooplankton taxa.

\section{Results}

\subsection{Inter-annual variation}

ANOVA results including years (1998-2009) and zones (inner and middle shelves, and oceanic domain; Figure 2) were the same as the results for ANOVA including years only. We also performed the analyses for each zone separately and the results still followed the same trend as the year comparisons alone. Therefore, only results from ANOVA by year are included in this paper. Significant inter-annual changes were observed in water mass properties (Table 1; Figures 3 and 4) and zooplankton abundance (Table 2, Figures 5-7) in May along the Seward line in the northern GOA. Mean temperatures below the pycnocline and mean temperatures in the upper $100 \mathrm{~m}$ were relatively higher $\left(>6.00^{\circ} \mathrm{C}\right)$ in 1998,2003 and 2005 , and lower $\left(\leq 5.00^{\circ} \mathrm{C}\right)$ in 2002 , 2007 and 2009 (Table 1; Figure 3a). Mean salinities in the upper $100 \mathrm{~m}$ and mean salinities above and below the pycnocline were relatively lower $(<32.20)$ in 2004 and 2005, and higher (> 32.20) in 1999, 2000 and 2001(Table 1; Figure 3b). Relatively high 
$\left(>6.00^{\circ} \mathrm{C}\right)$ mean temperatures above the pycnocline and enhanced stratification $(>50 \mathrm{~J}$ $\mathrm{m}^{-3}$ ) of the water column occurred in 1998, 2000, 2003, 2005, and 2009 (Table 1; Figures 3a and 4a). Stratification parameter was highest in 1998, 2000, 2003 and 2005 ranging between 58.77 and $69.68 \mathrm{~J} \mathrm{~m}^{-3}$ (Table 1; Figure 4a) and pycnocline depth was shallower in 2005 and 2009 than in 1999, 2001 and 2002 (Table 1; Figure 4b). Highest abundances of dominant copepod species (Pseudocalanus spp., Oithona spp., calanoid nauplii, Neocalanus plumchrus and N. flemingeri, and Metridia spp.) occurred in 1998, 2000, 2002, 2005 and 2006 and were lowest in 1999 and 2001 (Table 2, Figures 5a, 5b, 6d and 6 b-c). However, euphausiids showed different trends, with abundance peaks of Euphausia pacifica in 1999 and 2005, Thysanoessa inermis in 2001, 2002, 2007 and 2009, and Thysanoessa spinifera in 2000, 2001 and 2009 (Table 2, Figures 6 d-f). Oceanic copepod, E. bungii had highest abundance in 2006 and lowest abundance in 1998, while $N$. cristatus showed no significant inter-annual differences in abundance (Table 2; Figures 5e and f). Furthermore, copepods C. marshallae, Acartia spp. had highest abundance in 2005 and 2006 (Table 2; Figures 5c and 6a). Highest abundance of pterapods and chatognaths occurred in 2005 and 2003, respectively, while lowest abundance of larvaceans occurred in 2001 (Table 2; Figure 7a-c).

\subsection{GAM results}

Best-fit GAMs showed significant relationships between zooplankton abundance and water mass properties. Salinity had a significant effect on the abundance of 13 out of 15 zooplankton taxa and temperature had a significant effect on 9 taxa. Pycnocline depth 
did not have a significant effect on the abundance of any zooplankton taxa, while the stratification parameter had a significant effect on only two out of 15 zooplankton taxa (Table 3).

Calanus marshallae has the strongest GAM model which explained $74 \%$ of the variance in its abundance. Mean salinity above the pycnocline had strong negative effect on the abundance of $C$. marshallae, while mean salinity below the pycnocline and mean temperature below the pycnocline had a weaker effect on C. marshallae abundance (Table 3; Figure 8).

Pseudocalanus spp. and Acartia spp. abundances were negatively associated with mean salinity in the upper $100 \mathrm{~m}$ (Figures 8 and 10). Eucalanus bungii and Neocalanus cristatus were positively associated with mean salinity in the upper $100 \mathrm{~m}$ (Figure 10), such that E. bungii and N. Cristatus showed decreased abundance at $<31.6$ and $<32.3$ salinity respectivily. Mean salinity in the upper $100 \mathrm{~m}$ was negatively associated with Neocalanus plumchrus and Neocalanus flemingeri abundance when salinity values were approximately $>32.25$ (Figure 10). Mean salinity above the pycnocline, within the 31.60 to 32.75 range, had a significant effect on the abundances of Metridia spp. and calanoid nauplii; these groups were negatively associated with salinities $>32.60$ and $>32.50$, respectively (Figures 9 and 10). Oithona spp. was associated with mean salinity above the pycnocline, within the 32.00 to 32.75 range, and had a negative response to salinities > 32.30 (Figure 9). Mean salinity above the pycnocline within the 31.50 to 32.75 range, had a significant effect on the abundance of larvaceans, which exhibited a variable response within this range. Larvaceans showed an increase in abundance and small 
confidence intervals at 32.00 and 32.50 salinities and a decrease in abundance at 31.50 and 32.75 salinities (Figure 11). Thysanoessa spinifera were associated within a narrow mean salinity range $32.25-32.50$ below the pycnocline (Figure 11).

Mean temperature in the upper $100 \mathrm{~m}$ had a weak effect on the abundance of Eucalanus bungii, a negative effect on the abundance of Thysanoessa inermis and a positive effect on pteropods (Figures 10, 11 and 12). Furthermore, Pseudocalanus spp. and Euphausia pacifica had a positive response to mean temperatures in the upper $100 \mathrm{~m}$ between 5.75 and $6.25^{\circ} \mathrm{C}$ and between 4.5 and $5.5^{\circ} \mathrm{C}$, respectively (Figures 8 and 11 ). Mean temperature above the pycnocline had a weak effect on the abundance of calanoid nauplii and a positive effect on the abundance of Oithona spp. when temperatures were 6$7^{\circ} \mathrm{C}$ (Figure 9). In addition, mean temperature below the pycnocline was positively associated with the abundance of Chaetognatha (Figure 11). Finally, Pseudocalanus spp. and pteropods were associated with stratification parameters near $60\left(\mathrm{~J} \mathrm{~m}^{-3}\right)$ (Figures 8 and 12).

\section{Discussion}

This study showed a wide range of associations between zooplankton abundance and water mass properties, suggesting complex interactions of abiotic and biotic factors that influence zooplankton distribution and abundance in the northern GOA. Mixing processes can influence the distribution of zooplankton species, such that oceanic species are advected onshore into the coastal habitat and neritic species offshore over the slope (Coyle et al., 2013; Coyle et al., 2012; Mackas and Coyle, 2005). These processes 
include seasonal changes in winds and Ekman transport and interactions of currents with the complex coast and bathymetry that can generate eddies and meanders that enhance cross-shelf transport of water masses (Janout et al., 2009; Okkonen et al., 2003;

Weingartner et al., 2005). Species that are abundant in the upper mixed layer such as Neocalanus plumchrus and $N$. flemingeri are more likely to be advected onshore by Ekman transport, while species that are abundant below the mixed layer such as $N$. cristatus and Eucalanus bungii are less likely to be advected onshore by surface currents (Coyle and Pinchuk, 2005). Taxa that undergo diel vertical migration such as Metridia spp. and euphausiids will be influenced by Ekman transport at night and subsurface flow during the day.

Many of the zooplankton in the GOA are herbivorous and depend on high primary productivity. The GOA basin is a nitrate-rich-iron-limited environment (Wu et al., 2009), but the ACC is iron-rich and nitrate is limited in late spring and summer (Childers et al., 2005; Strom et al., 2007; Wu et al., 2009). Physical processes that enhance cross-shelf mixing should elevate primary production and may result in higher zooplankton abundance (Coyle et al., 2013; Coyle et al., 2012). Therefore, the intensity and timing of these abiotic and biotic processes may affect zooplankton abundance in the northern GOA.

\subsection{Climate variablibily and changes in zooplankton abundance}

The data presented in this study overlapped with positive and negative phases of the Pacific Decadal Oscillation (PDO) and El Nino Southern Oscillation (ENSO). The effects of ENSO events in the northern GOA are mainly manifested in winter/spring and 
have been observed to influence water mass properties in May (Weingartner et al., 2005). The year of 1998 was the end of positive PDO phase and also a 1997-98 El Nino event, while 1999-2002 corresponded to a negative phase of the PDO including two La Nina events in 1998-99 and 1999-2000, followed by a positive phase of the PDO from 2003 2006 and a negative PDO phase from 2007-2009, with an El Nino event in 2002-03 and a La Nina event in 2007-08 (http://research.jisao.washington.edu/pdo/; http://www.cpc.noaa.gov/products/analysis_monitoring/ensostuff/ensoyears.shtml). Mean temperature and salinity values observed in this study show the occurrence of cool and saline waters during negative phases of the PDO and La Nina years, and warm and low salinity waters during positive phases of the PDO and El Nino years. Neritic ( $T$. inermis and T. spinifera) and oceanic euphausiids (E. pacifica) showed opposing trends in abundance during PDOs of the same phase, such that neritic (oceanic) species had an increasing (decreasing) trend in abundance during the negative PDO phase and oceanic (neritic) species had and increasing (decreasing) trend in abundance during the positive PDO phase. E. pacifica is close to its northernmost range in the GOA, such that it may benefit from higher mean water temperatures. T. inermis on the other hand benefits from colder water temperatures in the winter (Pinchuk et al., 2008). During the cool and saline years of the moderate negative PDO phase from 1999-2002, abundances of oceanic (Neocalanus plumchrus/N.flemingeri; Neocalanus cristatus and Eucalanus bungii) and neritic copepods (Pseudocalanus spp., Acartia spp., and Calanus marshallae) were highly variable, however most copepods showed a decreasing trend in abundance during the cool and saline years of a stronger negative PDO phase from 2007-2009 and an 
increasing trend during the positive 2003-06 PDO phase. Lowest copepod abundance occurred in 2001 and was represented by neritic species (Pseudocalanus spp. and $C$. marshallae) and species that occur across the entire shelf and within the mixed layer (Oithona spp. and N. plumchrus/N.flemingeri). Winter conditions from 1999-2000 La Nina may have had a stronger influence on inner-shelf waters above the pycnocline than in the oceanic domain and waters below the pycnocline, such that oceanic species $E$. bungii and diel vertical migrating copepod species Metridia spp. did not show significant low abundances in 2001. The inconsistencies in copepod abundance trends between PDOs of the same phase may be partially explained by the dynamic nature of the GOA shelf environment and the complex life history of the zooplankton community.

\subsection{Inter-annual variability and zooplankton associations with water mass properties}

Thysanoessa inermis was abundant in 2001, 2002, 2007 and 2009. Thysanoessa inermis is mostly herbivorous, releases eggs only once per spawning season, and relies on lipid storages to overwinter (Falk-Petersen, 1981; Falk-Petersen et al. 1981; Pinchuk and Hopcroft, 2006). Furthermore, this species is characteristic of the shelf environment and may benefit from enhanced primary productivity during the spring bloom (April-May) (Coyle and Pinchuk, 2005; Lu et al., 2003; Pinchuk et al., 2008). Previous studies suggest that increases in the abundance of $T$. inermis are largely dependent on body condition before the spring bloom and that high chlorophyll $a$ concentrations are required to renew energy requirements after spawning (Falk-Petersen 1981; Falk-Petersen et al., 2000). Hence, cold conditions in winter and early spring would lower metabolic rates 
and result in slow consumption of lipid stores and therefore stronger body condition in spring (Pinchuk et al., 2008). Temperatures during the winters of 2001-2002, 2006-2007, 2007-2008 and 2008-2009 were anomalously low on the inner shelf in the northern GOA, with mean water column temperatures $<5^{\circ} \mathrm{C}$ compared to mean water column temperatures of $\sim 6^{\circ} \mathrm{C}$ in the other winters (1998-2001; 2002-2006) (Janout et al., 2010). High abundances of T.inermis in 2001, 2002, 2007 and 2009 after previous years of anomalous low temperature support the concept that cooler temperatures contribute to increased abundance of this species.

Euphausia pacifica is a subtropical-temperate species and is close to the northern boundary of its distribution in the GOA, which is dominated by subarctic species (Brinton, 1962; Mauchline and Fisher, 1969). In the present study warm water temperatures were favorable to higher abundances of E. pacifica as observed in 1999 and 2005, while colder water temperatures were limiting to high abundances of E. pacifica as observed in 2002, 2007 and 2009, when mean temperatures in the upper $100 \mathrm{~m}$ were anomalously low. GAM results suggest that an increase in water temperature in the upper $100 \mathrm{~m}$ contributes to an increase in abundance in E. pacifica until it reaches a temperature threshold of $5.5^{\circ} \mathrm{C}$ above which temperatures exert no consistent effect in its abundance.

Pteropods and chaetognaths were positively associated with mean temperature in the upper $100 \mathrm{~m}$ and below the pycnocline, respectively. Increased abundance of chaetognaths has been associated with increased temperatures in the southeastern Bering Sea and in the Kuroshio region in the western North Pacific (Baier and Terazaki, 2005; 
Nakata and Koyama, 2003). Furthermore, when water temperatures are higher later in the year (July-October), chaetognaths reach their highest abundance and biomass (Coyle and Pinchuk, 2003). Many chaetognath species are known to undergo diel vertical migration; however, smaller individuals can remain at the surface, therefore being exposed to more mixing within the mixed layer (Brodeur and Terazaki, 1999). High abundances of pteropods in 1998, 2003, 2005 and 2006 occurred when mean temperature in the upper $100 \mathrm{~m}$ and stratification parameter were highest, except for 2006 when water column properties were average. Pterapods were one of the few species to show a positive association with water column stability. Many pterapods are passive feeders that capture food using a spherical mucous web several times the size of their body (Gilmer, 1972; Gilmer and Harbison, 1986) and may benefit from a more stable water column given that intense mixing could damage the mucus web and make it difficult to capture food.

\subsection{Model analyses on selected species and their habitat - GAMs}

Variations in the abundance of Pseudocalanus spp. include the response of several species that occur in the northern GOA (P. minutus, P. moultani, P. newmani, $P$. mimus) (Napp et al., 2005). GAMs showed the association of Pseudocalanus spp. with neritic waters which were warm, stratified and had low salinities. Their abundance was highest in years of low salinity, high temperature and stratification parameter. The negative trend of Pseudocalanus spp. populations with salinity detected by the GAMs, 
indicates that the GAMs extracted the general trend in the data, which may not hold for individual years.

Calanus marshallae is a neritic species and is most abundant in the upper $40 \mathrm{~m}$ (Coyle and Pinchuk, 2005). C. marshallae was most abundant in 2005 and 2006, and had elevated abundance from the inner to the outer shelf. In 2005 and 2006 mean salinity above the pycnocline was low and the 32.25 isohaline extended to the end of the Seward line and the 32.50 isohaline extended to the middle shelf (GAK 6) (Figures 1and 13). Salinities $<32.25$ and $>32.50$ are characteristic for the ACC and oceanic waters, respectively (Weingartner et al., 2005). This suggests that enhanced cross-shelf mixing of near-surface coastal waters with offshore waters enhances $C$. marshallae concentrations. The cross-shelf advection in the Ekman layer promotes primary production by mixing low-nitrate high-iron coastal water with low-iron high-nitrate oceanic water. C. marshallae is an herbivorous species and is likely to benefit from increased primary production (Baier and Napp, 2003).

Neocalanus cristatus and Eucalanus bungii had a positive response to mean salinity in the upper $100 \mathrm{~m}$, reflecting their association with oceanic waters. E. bungii showed inter-annual variation in abundance. Conversely, there were no significant interannual differences in the abundance of $N$. cristatus. GAM results suggest that E. bungii abundance increases until salinity is about 31.5 and is fairly constant afterwards. Thus, they appear to tolerate a broad spectrum of environmental conditions and are thus likely to occur at most stations along the Seward line. However, $N$. cristatus populations do not peak until salinity is greater than 32.3 . These observations suggest that these animals 
may be intolerant of the lower salinity associated with the ACC. The vertical distribution of $N$. cristatus and E. bungii is different from the other Neocalanus spp., in that their populations are highest in the 20-40 m depth, below the Ekman layer (Coyle and Pinchuk, 2005). This means that they are less likely to be advected onshore by downwelling conditions. The GAMs appear to reflect a vertical distribution which limits the cross-shelf advection of $N$. cristatus and E. bungii relative to other species which are most abundant in the upper $20 \mathrm{~m}$. Therefore the GAMs reflect the tolerance of $N$. cristatus and E. bungii not only to salinity and temperature, but also their susceptibility to cross-shelf transport.

There was a sharp decrease in calanoid nauplii, Oithona spp. and Metridia spp. abundance when salinity exceeded 32.5 in the upper mixed layer. Calanoid nauplii can be from any calanoid species and differences in species composition are likely to contribute to broader confidence intervals and standard errors. Oithona spp. and Metridia spp. on the other hand, are dominated by one species each (Oithona similis and Metridia pacifica, respectively) (Coyle and Pinchuk, 2003; Coyle and Pinchuk, 2005), so differences in species composition are less likely to affect confidence intervals and standard errors. High subsurface chlorophyll $a$ concentrations associated with eddy activity and salinities $<32.2$ may have contributed to the high abundance of these taxa in 2000 and 2002 (Coyle and Pinchuk, 2005; Janout et al., 2009). Low abundances of calanoid nauplii, relative to other years, may be partially explained by the cruise date (2328 May, 2003) being almost three weeks later than the other cruises in our study. 
Neocalanus plumchrus/N. flemingeri were abundant in 1998, 2002 and 2006 when the 32.25 isohaline extended to the end of the Seward line $(1998,2006)$ and to the shelf break (GAK 9, 2002), and the 32.50 isohaline extended to the inner (GAK 4, 1998,2002) and middle shelves (GAK 7, 2006) (Figures 1 and 13). Salinities $<32.25$ and $>32.50$ are characteristic of the ACC and oceanic waters, respectively, which suggests that the Seward line was characterized by considerable cross-shelf mixing of oceanic and shelf water salinity during these years. Neocalanus plumchrus/N. flemingeri feed mainly on phytoplankton and microzooplankton (Dagg et al., 2006; Liu et al., 2008; Strom et al., 2007). Their abundance appears to increase when mixing of iron-poor nutrient-rich oceanic water and nutrient-poor iron-rich shelf waters occurs. Wind and eddy activity often influence cross-shelf mixing and may contribute to enhanced production of chainforming diatoms and associated microzooplankton communities (Janout et al., 2009; Okkonen et al., 2003; Strom et al. 2007). These conditions may have contributed to the high abundances of $N$. plumchrus/N. flemingeri during this period.

In 2002 there was intense eddy activity along the Seward line (Coyle and Pinchuk, 2005; Janout et al., 2009; Okkonen et al., 2003) and Calanus marshallae, Neocalanus plumchrus/N. flemingeri and Thysanoessa inermis had high abundances during this period. Calanus marshallae occurs along the coast and south towards Oregon in the upwelling region, where production is elevated and temperatures are lower. Thysanoessa inermis is a circumpolar arctic species that relies on lipid storage to overwinter (Baier and Napp, 2003; Falk-Petersen, 1981; Peterson, 1998). Anomalously cold conditions in winter and early spring in 2002 (Janout et al., 2010) may have 
contributed to higher overwintering survival of Calanus marshallae and Thysanoessa inermis. Neocalanus plumchrus/N. flemingeri were likely unaffected by colder conditions in the upper $100 \mathrm{~m}$, since they overwinter in deeper water (Miller and Clemons, 1988) and perhaps differences in the timing and intensity of the spring phytoplankton bloom may have contributed to their elevated abundances in 2002.

\section{Conclusions}

The northern GOA has undergone significant variations in temperature, salinity and zooplankton abundance in the month of May from 1998-2009. High zooplankton abundances in years of substantial cross-shelf mixing suggest that iron and nutrient transport between the shelf and oceanic domains are essential for sustaining high copepod populations through large phytoplankton blooms. The abundance of zooplankton in the northern GOA is highly influenced by advective processes and changes in temperature. Their complex life histories, vertical distribution patterns and habitat associations, have a major influence on the response of each taxon to changes in environmental conditions. Further understanding of biological and physical mechanisms that control the GOA ecosystem are of major importance to predict the response of zooplankton communities to environmental change

\section{Acknowledgements}

This research was conducted on the RV Alpha Helix. Technical support was provided by the captain, crew and ship technicians. We also thank Chris Stark, Elizabeth 
Stockmar, Carla Delfino, Dr. Alexei Pinchuk and Janet Ballek for assisting in the zooplankton sample processing and data entry. This research was multidisciplinary, involving the cooperation of a number of researchers, especially Amy Childers, Seth Danielson, Dr. Dean Stockwell and Dr. Terry Whitledge. Finally, we thank three anonymous reviewers and the Editor for their conscientious comments that improved the manuscript. L. de Sousa was supported by the National Science Foundation Graduate Fellowship, National Fish and Wildlife Foundation and University of Alaska Graduate School. The Long-Term Observation Program was supported by the US GLOBEC program, jointly funded by the National Science Foundation and the National Oceanic and Atmospheric Administration under the Grants OCE-0105236 and NA67RJ0147AMD7 and by the North Pacific Research Board projects 506, 603, 8708, 804 and 1002.

\section{References}

Anderson, P.J., Piatt, P.J., 1999. Community reorganization in the Gulf of Alaska following ocean climate regime shift. Mar. Ecol. Prog. Ser. 189, 117-123.

Armstrong, J.L., Boldt, J.L., Cross, A.D., Moss, J.H., Davis, N.D., Myers, K.D., Walker, R.V., Beauchamp, D.A., Haldorson, L.J., 2005. Distribution, size, and interannual, seasonal and diel food habits of northern Gulf of Alaska juvenile pink salmon, Oncorhynchus gorbuscha. Deep-Sea Res. II 52, 247-265.

Baier, C.T., Napp, J.M., 2003. Climate-induced variability in Calanus marshallae populations. J. Plankton Res. 25, 771-782. 
Baier, C.T., Terazaki, M., 2005. Interannual variability in a predator-prey interaction: climate, chaetognaths and copepods in the southeastern Bering Sea. J. Plankton Res. 27, 1113-1125.

Brinton, E., 1962. The distribution of Pacific euphausiids. Bull. Scripps Inst. Oceanogr. $8,21-270$.

Brodeur, R.D., Terazaki, M., 1999. Springtime abundance of chaetognaths in the shelf region of the northern Gulf of Alaska, with observations on the vertical distribution and feeding of Sagitta elegans. Fish. Oceanogr. 8, 93-103.

Childers, A.R., Whitledge, T.E., Stockwell, D.A., 2005. Seasonal and interannual variability in the distribution of the nutrients and chlorophyll $a$ across the Gulf of Alaska shelf: 1998-2000. Deep-Sea Res. II 52, 193-216.

Coyle K.O., Pinchuk, A.I., 2003. Annual cycle of zooplankton abundance, biomass and production on the northern Gulf of Alaska shelf, October 1997 through October 2000. Fish. Oceanogr. 12, 327-338.

Coyle K.O., Pinchuk, A.I., 2005. Seasonal cross-shelf distribution of major zooplankton taxa on the northern Gulf of Alaska shelf relative to water mass properties, species depth preferences and vertical migration behavior. Deep-Sea Res. II 52, 217-245.

Coyle, K.O., Gibson, G.A., Hedstrom, K., Hermann, A.J., Hopcroft, R.R., 2013. Zooplankton biomass, advection and production on the northern Gulf of Alaska shelf from simulations and field observations. J. Mar. Syst., 128, 185-207. 
Coyle, K.O., Cheng, W., Hinckley, S.L., Lessard, E.J., Whitledge, T., Hermann, A.H, Hedstrom, K., 2012. Model and field observations of effects of circulation on the timing and magnitude of nitrate utilization and production on the northern Gulf of Alaska shelf. Prog. Oceanogr. 103, 16-41.

Dagg, M.J., Liu, H., Thomas, A.C., 2006. Effects of mesoscale phytoplankton variability on the copepods Neocalanus flemingeri and N. plumchrus in the coastal Gulf of Alaska. Deep-Sea Res. I 53, 321-332.

Falk-Petersen, S., 1981. Ecological investigations on the zooplankton community of Balsfjorden, Northern Norway: Seasonal changes in body weight and the main biochemical composition of Thysanoessa inermis (Kroyer), Thysanoessa raschii (M. Sars), and Meganyctiphanes norvegica (M. Sars) in relation to environmental factors. J. Exp. Mar. Biol. Ecol. 49, 103-120.

Falk-Petersen, S., Gatten, R.R., Hopkins, C.C.E., Sargent, J.R., 1981. Ecological investigations on the zooplankton community of Balsfjorden, Northern Norway: seasonal changes in the lipid class composition of Meganyctiphanes norvegica (M. Sars), Thysanoessa raschii (M. Sars) and Thysanoessa inermis (Krøyer). J. Exp. Mar. Biol. Ecol. 54, 204-209.

Falk-Petersen, S., Hagen, W., Kattner, G., Clarke, A., Sargent, J. 2000. Lipids, trophic relationships, and biodiversity in Arctic and Antarctic krill. Can. J. Fish. Aquat. Sci. 57 (Suppl. 3), 178-191. 
Francis, R.C., Hare, S.R., 1994. Decadal-scale regime shifts in the large marine ecosystems of the north-east Pacific: a case for historical science. Fish. Oceanogr. 3, 279-291.

Gilmer, R.W., 1972. Free-floating mucus webs: a novel feeding adaptation for the open ocean. Science 176, 1239-1240.

Gilmer, R.W., Harbison, G.R., 1986. Morphology and field behavior of pteropod molluscs: feeding methods in the families Cavoliniidae, Limacinidae and Peraclididae (Gastropoda: Thecosomata). Mar. Biol. 91, 47-57

Hastie, T.J., Tibshirani, R.J., 1990. Generalized Additive Models. Chapman and Hall, New York, pp 325.

Hatch, S.A., Sanger, G.A., 1992. Puffins as samplers of juvenile pollock and other forage fish in the Gulf of Alaska. Mar. Ecol. Prog. Ser. 80, 1-14.

Janout, M.A., Weingartner, T.J., Okkonen, S.R., Whitledge, T.E., Musgrave, D.L. 2009. Some characteristics of Yakutat eddies propagating along the continental slope of the northern Gulf of Alaska. Deep-Sea Res. II 56, 2444-2459.

Janout, M.A., Weingartner, T.J., Royer, T.C., Danielson, S.L., 2010. On the nature of winter cooling and the recent temperature shift on the northern Gulf of Alaska shelf. J. Geophys. Res. 115, C05023, doi:10.1029/2009JC005774

Kobari, T., Ikeda, T., 2001a. Life cycle of Neocalanus flemingeri (Crustacea: Copepoda) in the Oyashio region, western subarctic Pacific, with notes on its regional variations. Mar. Ecol. Prog. Ser. 209, 243-255. 
Kobari, T., Ikeda, T., 2001b. Ontogenetic vertical migration and life cycle of Neocalanus plumchrus (Crustacea: Copepoda) in the Oyashio region, with notes on regional variations in body sizes. J. Plankton Res. 23, 287-302.

Liu, H., Dagg, J.M., Napp, J.M., Sato, R., 2008. Mesozooplankton grazing in the coastal Gulf of Alaska: Neocalanus spp. vs. other mesozooplankton. ICES J. Mar. Sci. $65,351-360$.

Lu, B., Mackas, D.L., Moore, D.F., 2003. Cross-shore separation of adult and juvenile euphausiids in a shelf-break alongshore current. Prog. Oceanogr. 57, 381-404

Mackas, D.L., Coyle, K.O., 2005. Shelf-offshore exchange processes, and their effects on mesozooplankton biomass and community composition patterns in the northeast Pacific. Deep-Sea Res. II 52, 707-725.

Mantua, N.J., Hare, S.R., Zhang, Y., Wallace, J.M., Francis, R.C., 1997. A Pacific interdecadal climate oscillation with impacts on salmon production. Bull. Am. Meteorol. Soc. 78, 1069-1079.

Mauchline, J., Fisher, L.R., 1969. The biology of euphausiids. Adv. Mar. Biol. 7, 1-454

Merrick, R.L., Loughlin, T.R., Calkins, D.G., 1987. Decline in the abundance of the northern sea lion, Eumetopia jubatus, in Alaska, 1956-86, U.S. Fish. Bull. 85, 351-365.

Miller, C.B., Clemons, M.J., 1988. Revised life history analysis for large grazing copepods in the Subarctic Pacific Ocean. Prog. Oceanogr. 20, 293-313 
Napp, J.M., Hopcroft, R.R., Baier, C.T., Clarke, C., 2005. Distribution and speciesspecific egg production of Pseudocalanus in the Gulf of Alaska. J. Plankton Res., $27,415-426$.

Nakata, K., Koyama, S., 2003. Interannual changes of the winter to early spring biomass and composition of mesozooplankton in the Kuroshio region in relation to climatic factors. J. Oceanogr. 59, 225-234.

Okkonen, S.R., Weingartner, T.J., Danielson, S.L., Musgrave, D.L. 2003. Satellite hydrographic observations of eddy-induced shelf-slope exchange in the northwestern Gulf of Alaska. J. Geophys. Res. 108, (15-1)-(15-10).

Peterson, W.T. ,1998. Life cycle strategies of copepods in coastal upwelling zones. J. Mar. Syst. 15, 313-326.

Pinchuk, A.I., Hopcroft, R.R., 2006. Egg production and early development of Thysanoessa inermis and Euphausia pacifica (Crustacea: Euphausiacea) in the northern Gulf of Alaska. J. Exp. Mar. Biol. Ecol. 332, 206-215.

Pinchuk, A.I., Coyle, K.O., Hopcroft R.R., 2008. Climate-related variability in abundance and reproduction of euphausiids in the northern Gulf of Alaska in 1998-2003. Prog. Oceanogr. 77, 203-216.

R Development Core Team, 2009. R: a language and environment for statistical computing. R Foundation for Statistical Computing, Vienna; www.R-project.org.

Reed, R.K., 1984. Flow of the Alaskan Stream and its variations. Deep-Sea Res. 31, 369-386. 
Reed, R.K, Schumacher J.D., 1986. Physical Oceanography. In Hood and Zimmerman (eds), The Gulf of Alaska Physical Environment and Biological Resources. Minerals Management Service publication number: OCS study, MMS 86-0095, pp. $57-75$

Reed, R.K., Stabeno, P.J., 1989. Recent observations of variability in the path and vertical structure of the Alaskan Stream. J. Phys. Oceanogr. 19, 1634-1642

Royer TC (1982) Coastal fresh water discharge in the northeast Pacific. J. Geophys. Res., 87, 2017-2021.

Siefert, D.L., 1994 The importance of sampler mesh size when estimating total daily egg production by Pseudocalanus spp. In Shelikof Strait, Alaska. J. Plank. Res. $16: 1489-1498$

Sigler, M.F., Rutecki, T.L., Courtney, D.L., Karinen, J.F., Yang, M.S., 2001. Young of the year sablefish abundance, growth, and diet in the Gulf of Alaska. Alaska Fish. Res. Bul. 8, 57-70.

Simpson, J.H., Hughes, D.G., Morris, N.C.G., 1977. The relation of seasonal stratification to tidal mixing on the continental shelf. Deep-Sea Res. 24 (Suppl.): 327-340.

Skjoldal, H.R., Wiebe, P.H., Postel, L., Knutsen, T., Kaartvedt, S., Sameoto, D.D., 2013. Intercomparison of zooplankton (net) sampling systems: Results from the ICES/GLOBEC sea-going workshop. Prog. Oceanogr. 108, 1-42

Smith, P.E., Flerx, W., Hewitt, R.P., 1985. The CalCOFI vertical egg tow (CalVET) net. In: Lasker R (ed.), An Egg Production Method for Estimating Spawning Biomass 
of Pelagic Fish: Application to the Northern Anchovy Engraulis mordox. NOAA Technical Report NMFS 36. Washington DC: US Department of Commerce, pp. 23-33.

Springer, A., 1998. Is it all climate change? Why marine birds and mammal populations fluctuate in the North Pacific. In: Holloway G, Muller P, Henderson D (eds.) Biotic Impacts of Extratropical Climate Variability in the Pacific. Proceedings ‘Aha Huliko’a Workshop, Manoa: Univ. Hawaii SOEST, pp. 109-120.

Stabeno, P.J., Bond, N.A., Hermann, A.J., Kachel, N.B., Mordy, C.W., Overland, J.E., 2004. Meteorology and oceanography of the Northern Gulf of Alaska. Cont. Shelf Res. 24, 859-897.

Strom, L.S., Macri, E.L., Olson, M.B., 2007. Microzooplankton grazing in the coastal Gulf of Alaska: variations in top-down control of phytoplankton. Limnol. Oceanogr. 52, 1480-1494.

Tsuda, A., Saito, H., Kasai, H., 1999. Life histories of Neocalanus flemingeri and Neocalanus plumchrus (Calanoida: Copepoda) in the western subarctic Pacific. Mar. Biol. 135, 533-544.

Tsuda, A., Hiroaki, S., Hiromi, K., 2004. Life histories of Eucalanus bungii and Neocalanus cristatus (Copepoda: Calanoida) in the western subarctic Pacific Ocean. Fish. Oceanogr. 13 (Suppl. 1), 10-20.

Ware, D.M., McFarlane, G.A., 1989. Fisheries production domains in the Northeast Pacific Ocean. In: Beamish RJ, McFarlane GA (eds.), Effects of Ocean Variability on Recruitment and the Evaluation of Parameters used in Stock 
Assessment Models. Canadian Special Publications of Fisheries and Aquatic Sciences. National Research Council of Canada, Ottawa, pp. 359-379.

Weingartner, T.J., Coyle, K.O., Finney, B., Hopcroft, R.R., Whitledge T.E., Brodeur, R., Dagg, M., Farley, E., Haidvogel, D., Haldorson, L., Hermann, A., Hinckley, S., Napp, J., Stabeno, P., Kline, T., Lee, C., Lessard, E., Royer, T., Strom, S., 2002. The northeast Pacific GLOBEC program: coastal Gulf of Alaska. Oceanogr. 15, 48-63.

Weingartner, T.J., Danielson, S.L., Royer, T.C., 2005. Freshwater variability and predictability in the Alaska Coastal Current. Deep-Sea Res. II 52, 169-191.

Wiebe, P.H., Burt, K.H., Boyd, S.H., Morton, AW. 1976. A multiple opening/closing net and environmental sensing system for sampling zooplankton. J. Mar. Research $34,313-325$.

Willette, T.M., Cooney, R.T., Patrick, V., Mason, D.M., Thomas, G.L., Scheel, D. 2001. Ecological processes influencing mortality of juvenile pink salmon (Oncorhynchus gorbuscha) in Prince William Sound, Alaska. Fisheries Oceanogr. 10 (Supp.1), 14-41.

Wood, S.N., 2004. Stable and efficient multiple smoothing parameter estimation for generalized additive models. Journal of the American Statistical Association 99, 673-686.

Wood, S.N. 2006. Generalized Additive Models: an Introduction with R. Chapman Hall/CRC, pp. 392. 
Wu, J., Aguilar-Islas, A., Rember, R., Weingartner, T., Danielson, S., Whitledge, T. 2009. Size-fractionated iron distribution on the northern Gulf of Alaska. Geophys. Res. Lett., VOL. 36, L11606, doi:10.1029/2009GL038304, 2009.

Zar, J.H., 1999. Biostatistical Analysis. Prentice Hall Inc. $4^{\text {th }}($ ed), New Jersey, USA, pp. 123. 


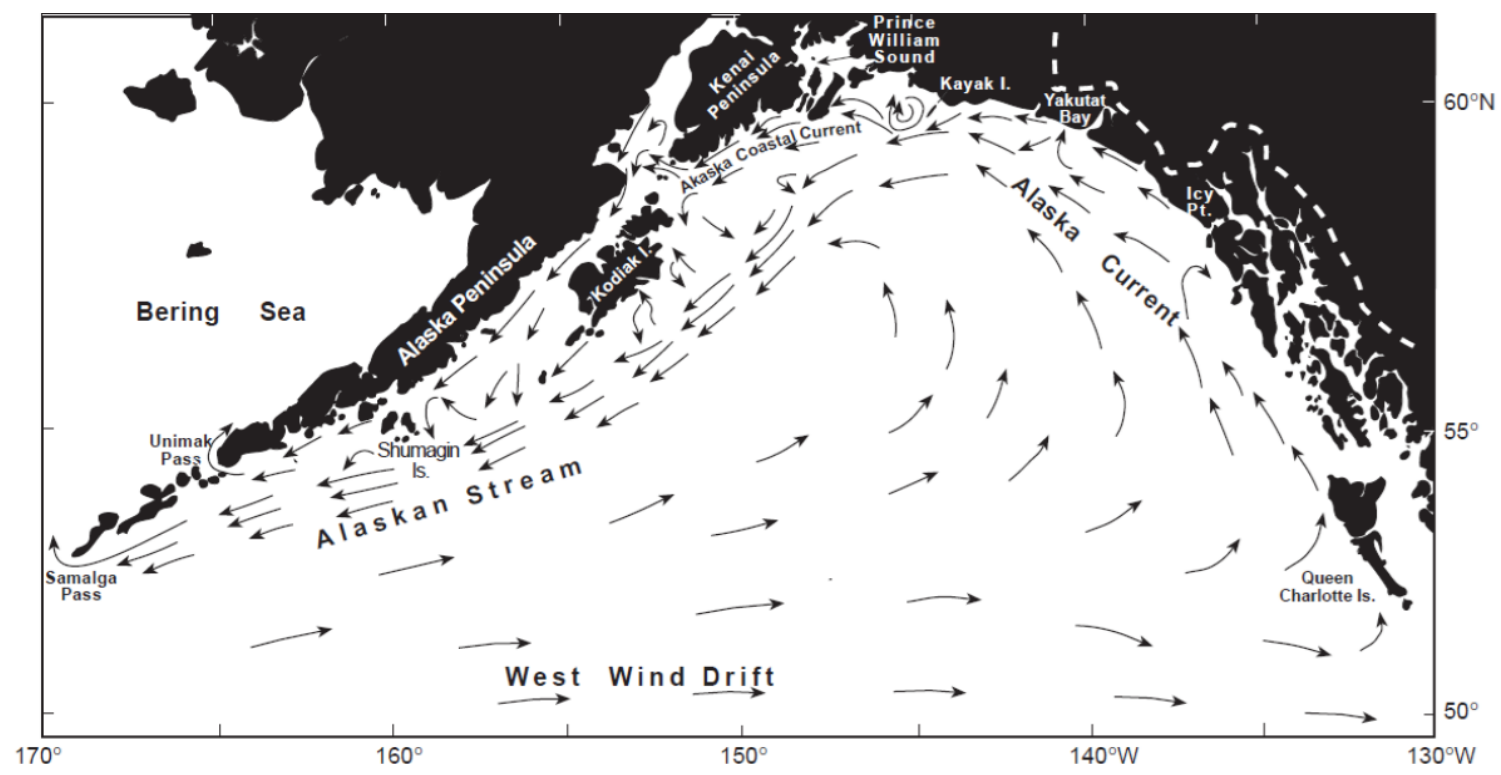




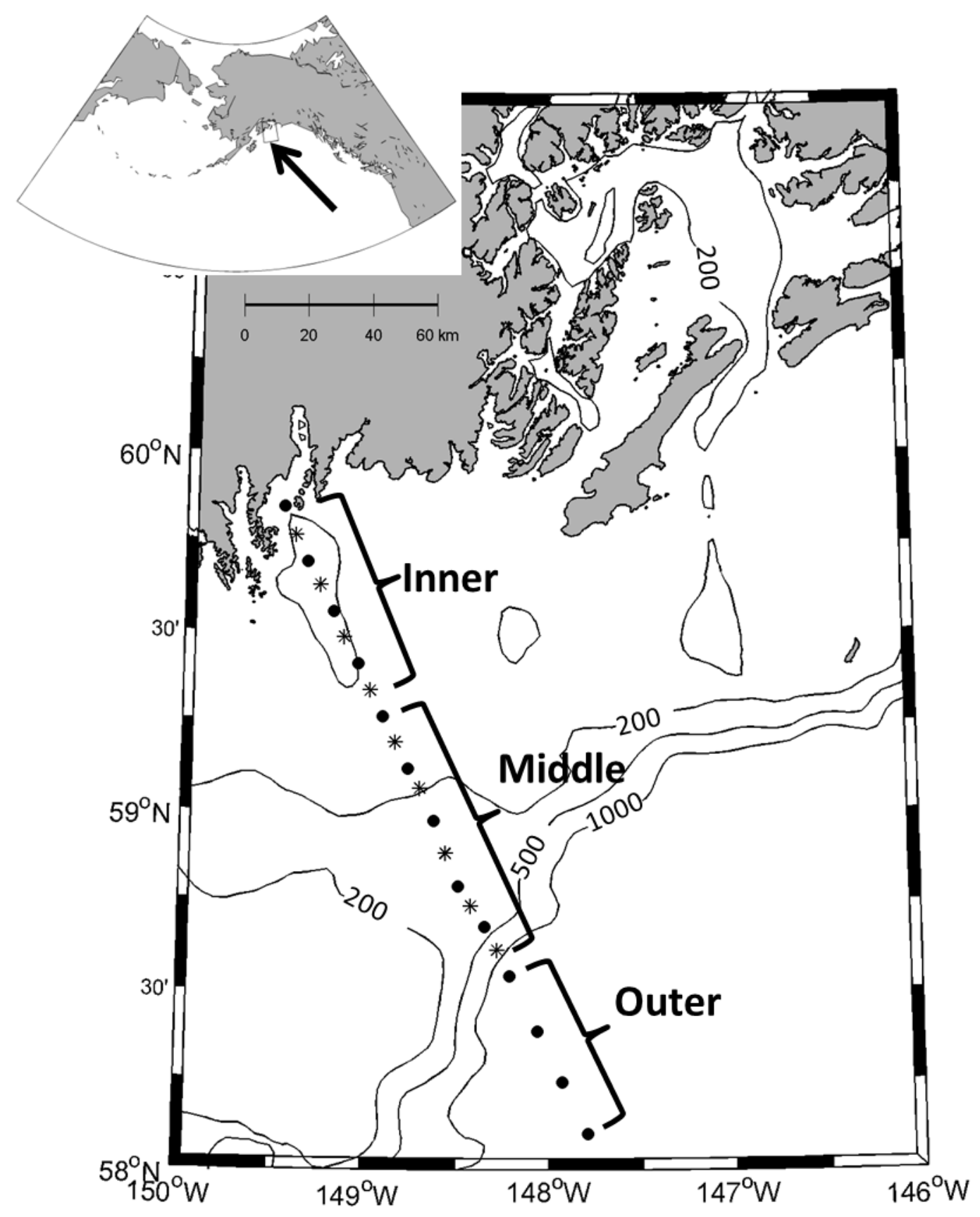



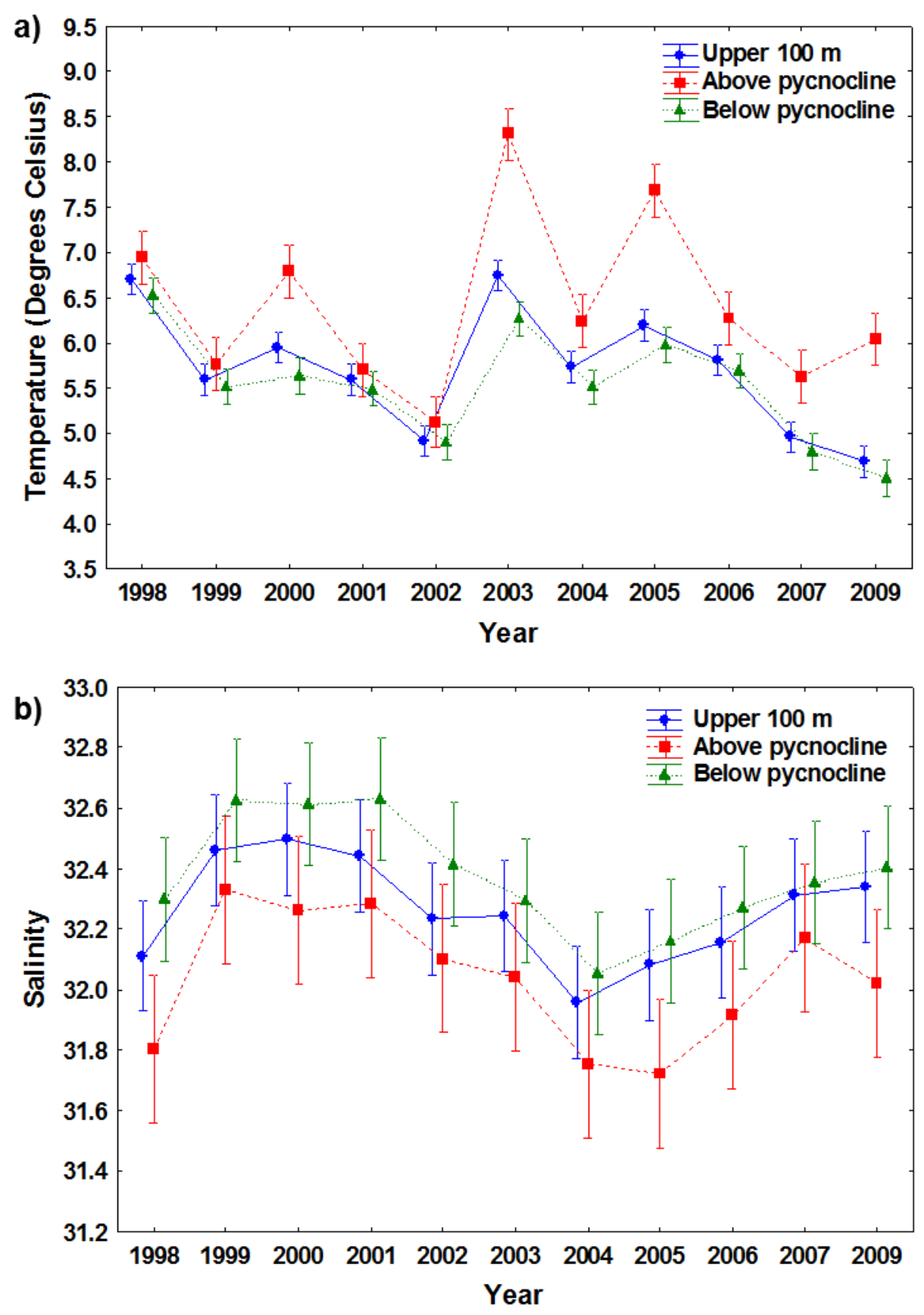

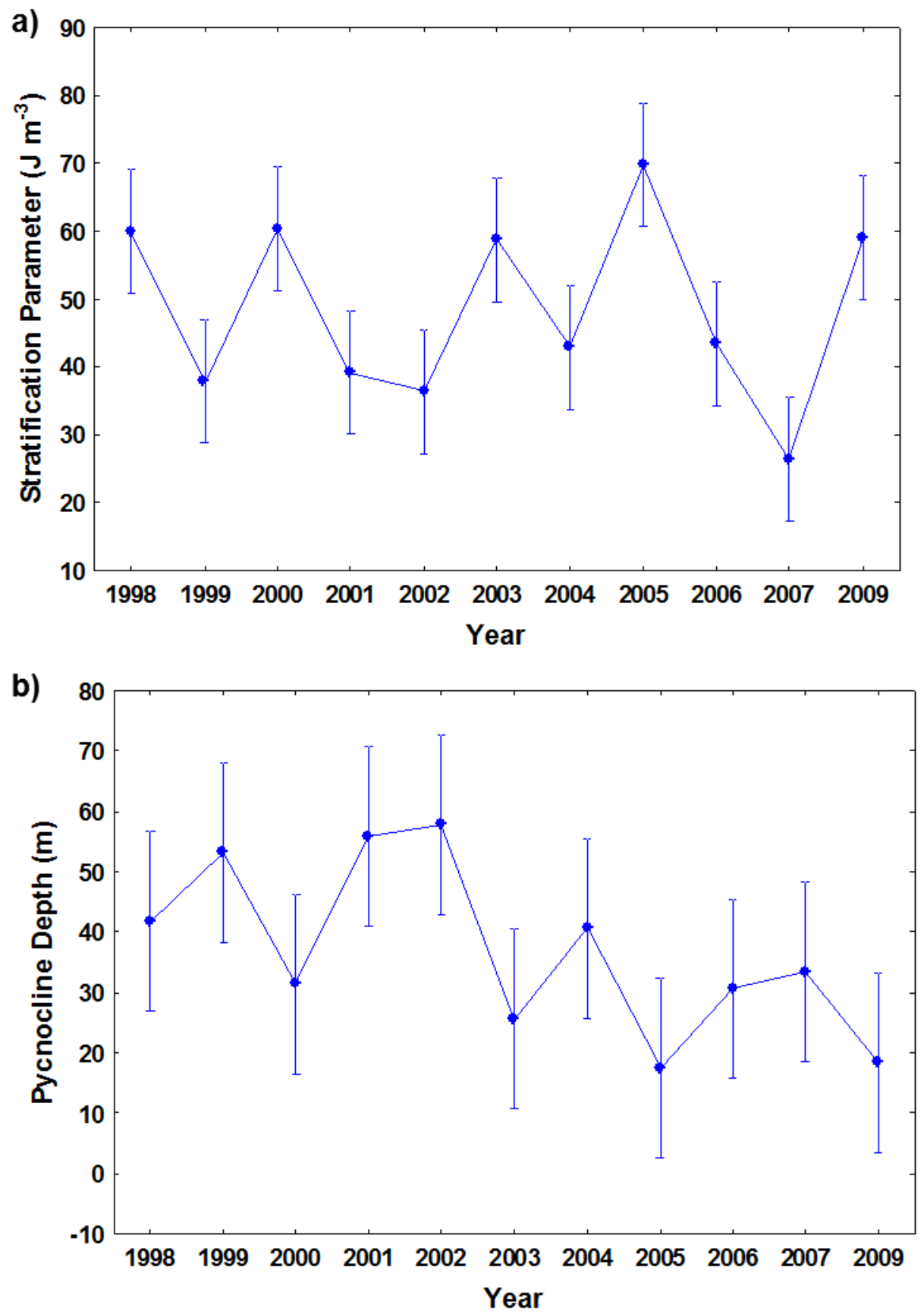

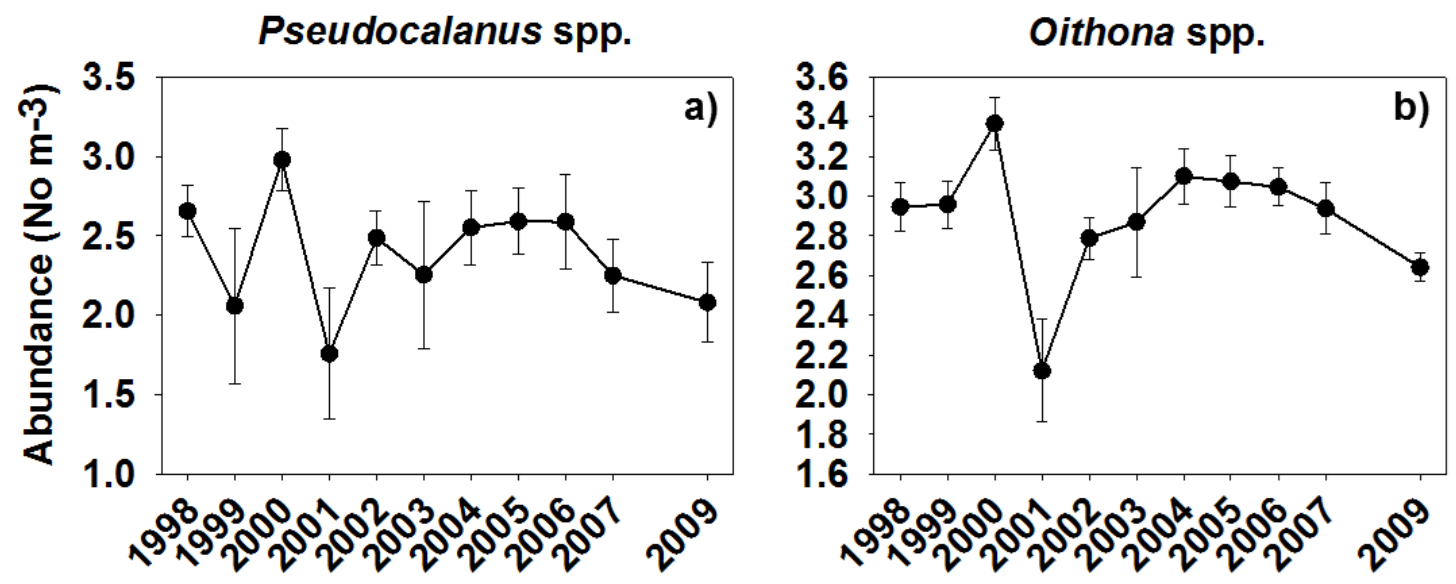

Acartia spp.

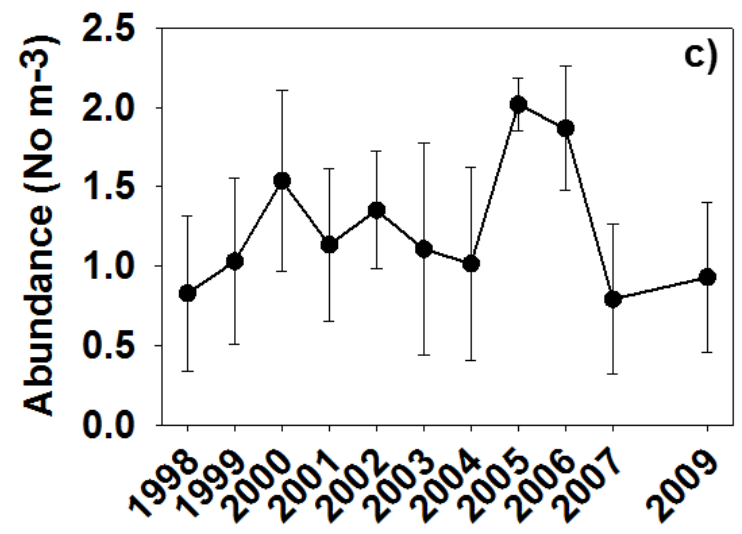

Calanoid nauplii
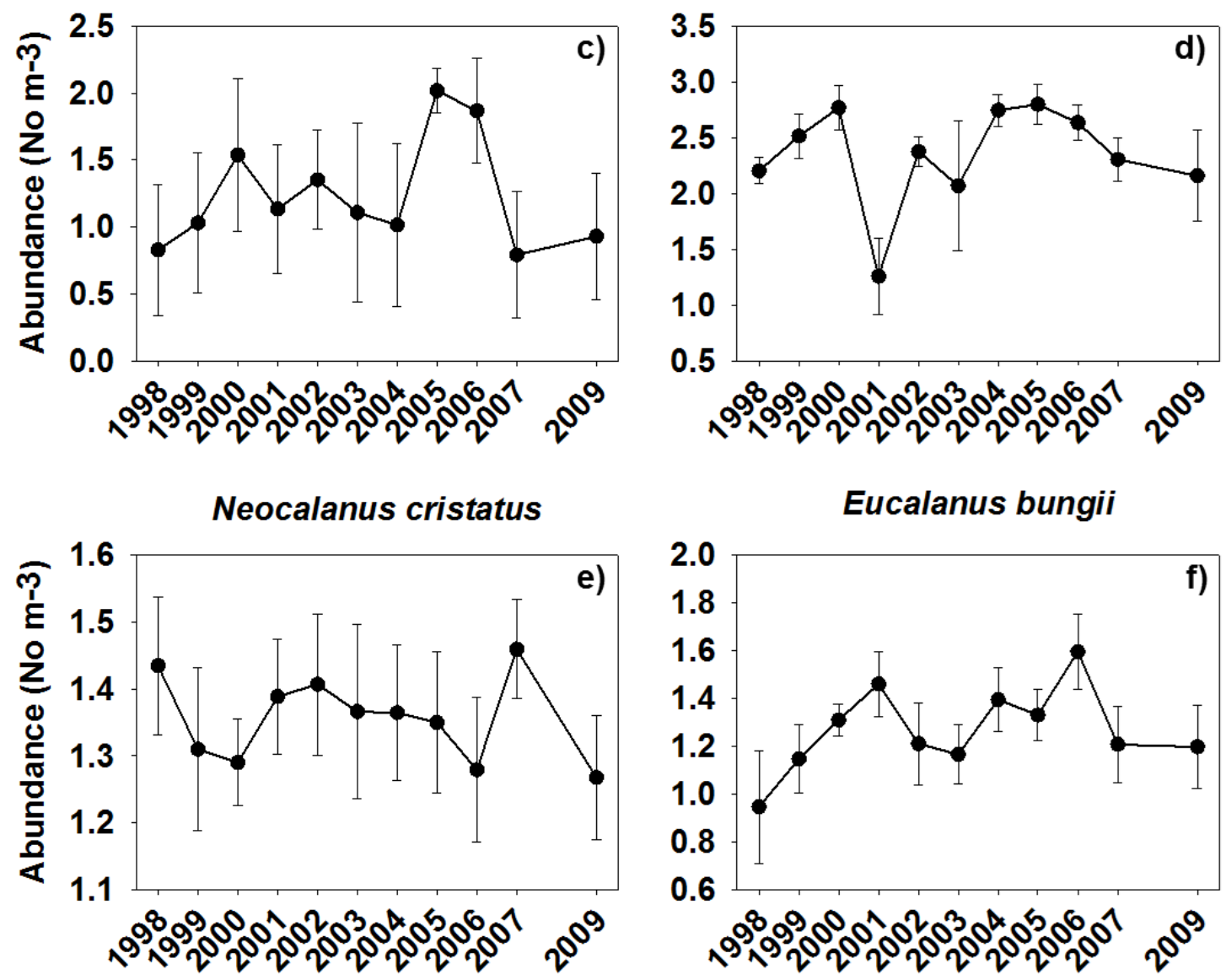

Eucalanus bungii

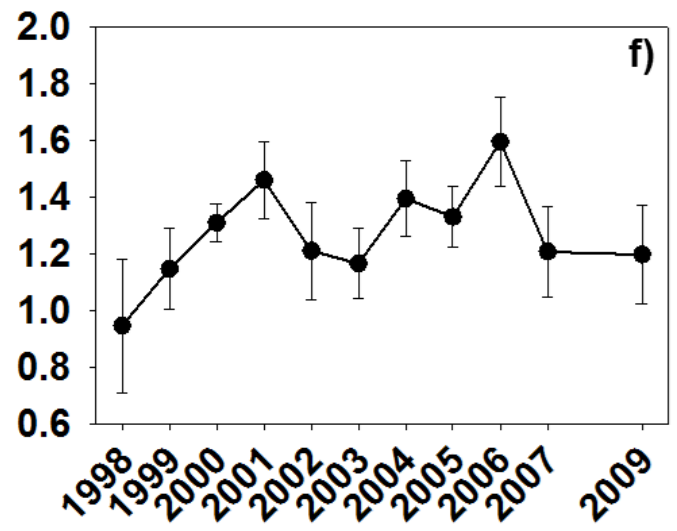



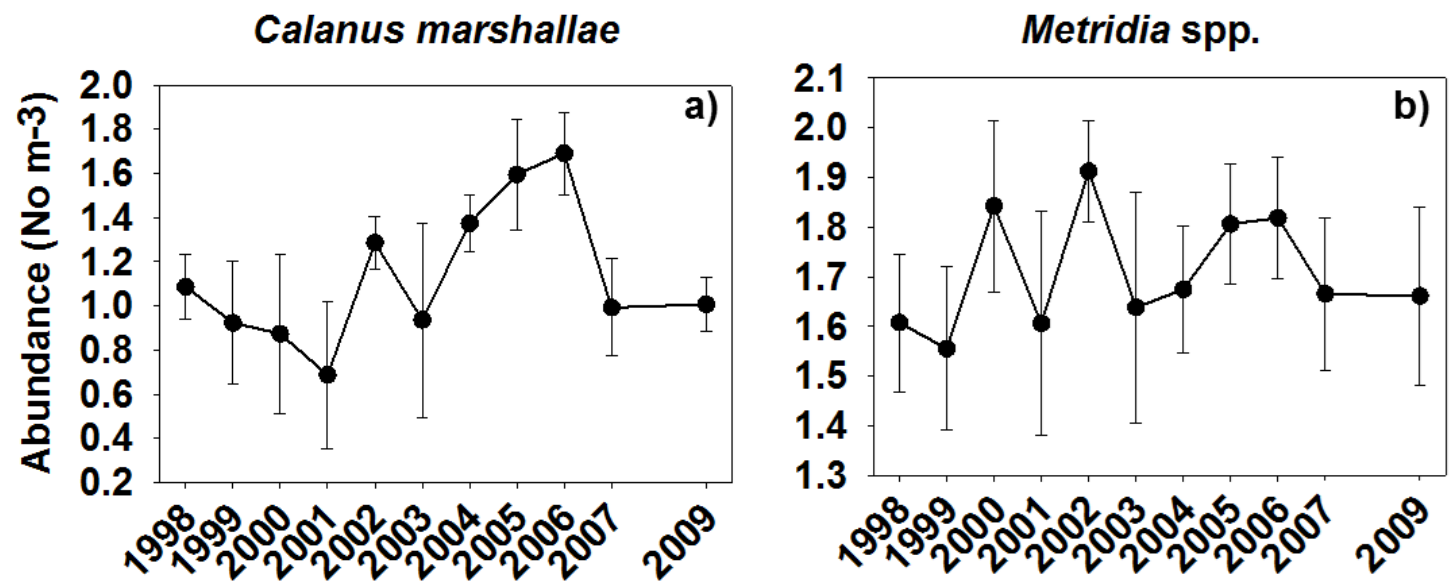

N. plumchrus/N. flemingeri

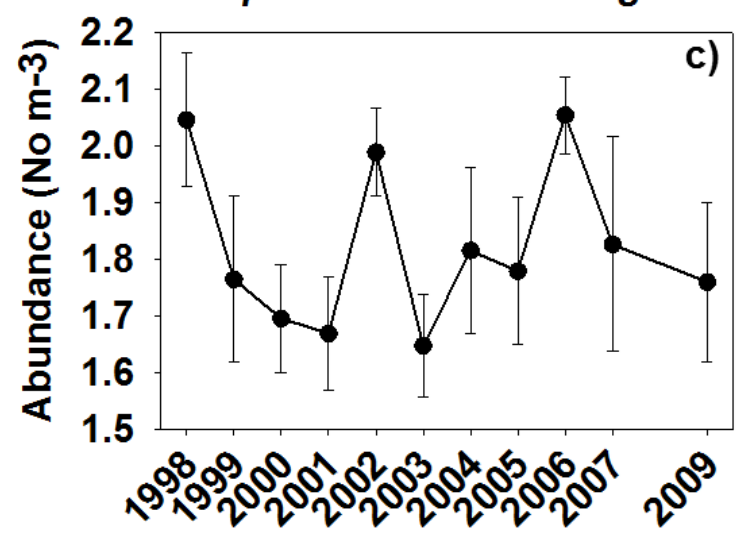

Thysanoessa inermis

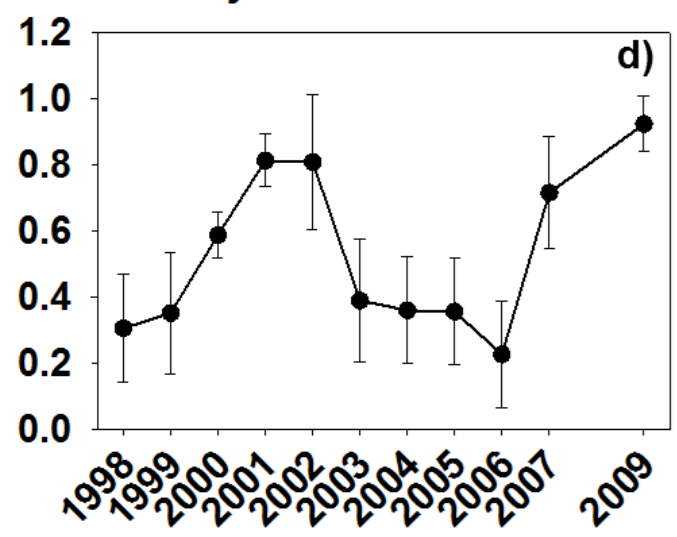

Euphausia pacifica

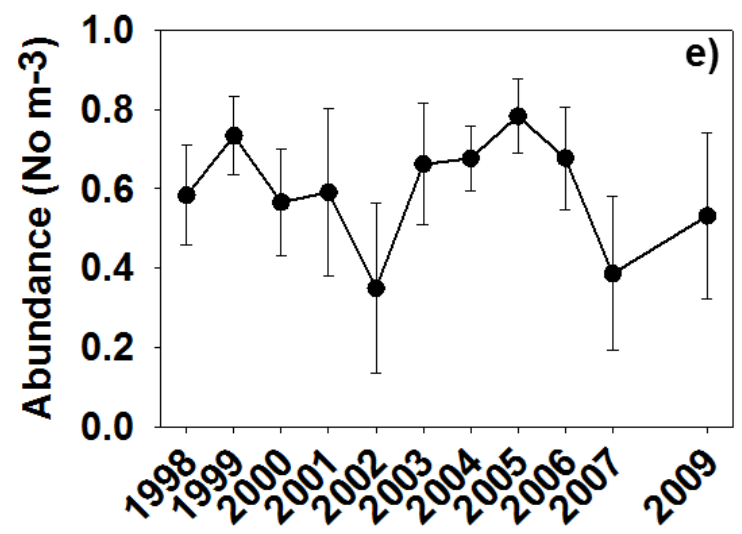

Thysanoessa spinifera

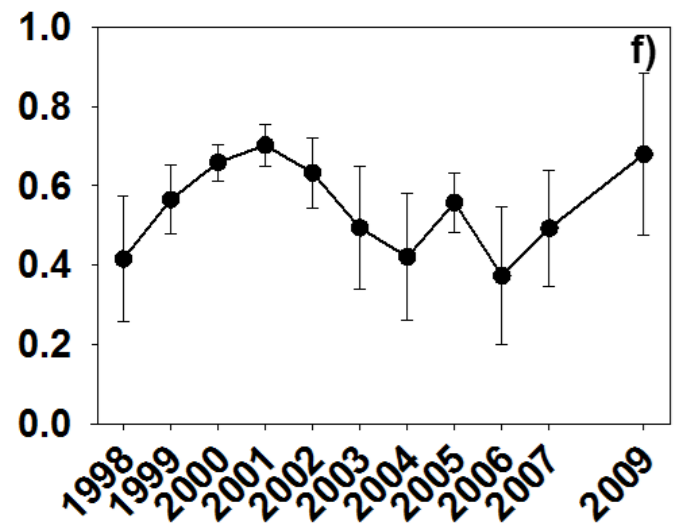



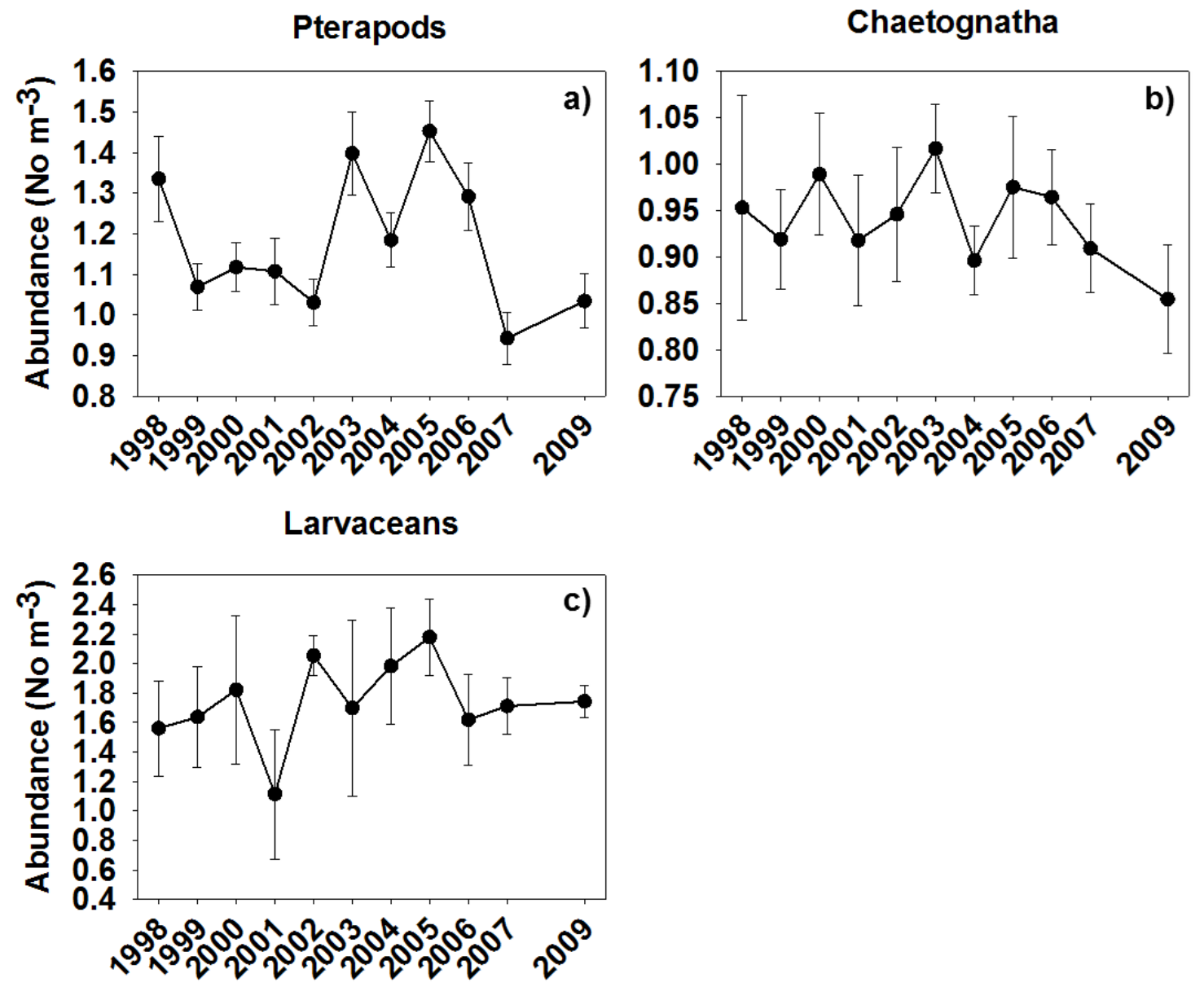


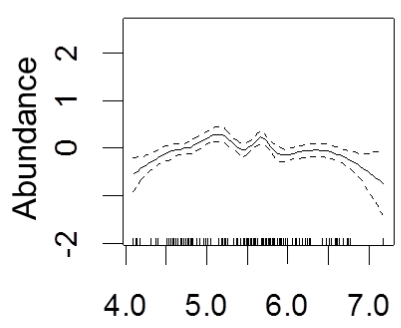

temperature below pycnocline

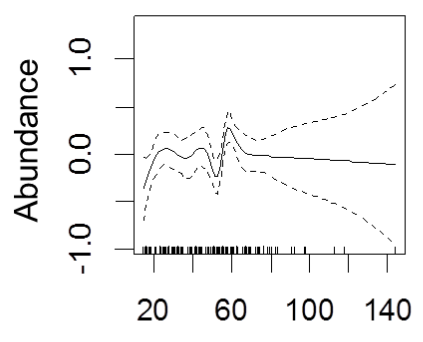

stratification parameter

\section{Calanus marshallae}

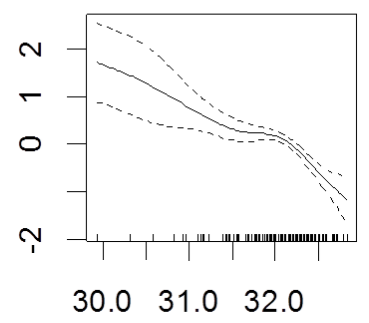

salinity above pycnocline

Pseudocalanus spp.

$\bar{\omega}$

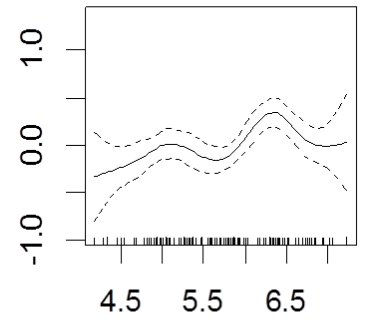

mean temperature

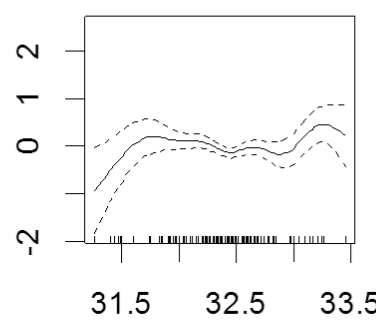

salinity below pycnocline

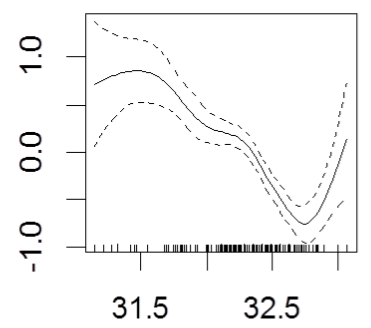

mean salinity 


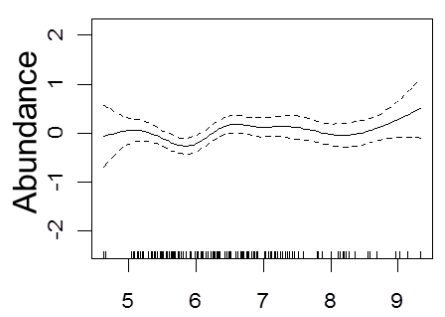

temperature above pycnocline

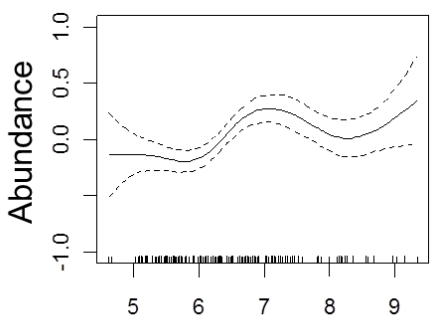

temperature above pycnocline

\section{Calanoid nauplii}

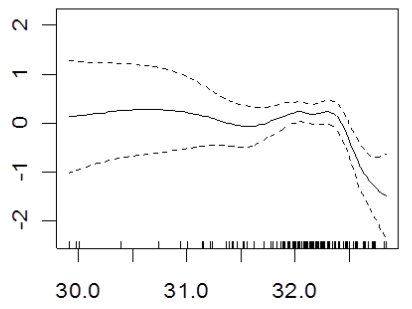

salinity above pycnocline

Oithona spp.

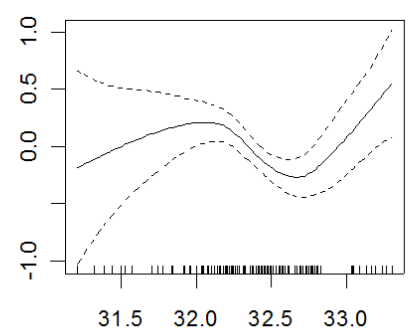

salinity below pycnocline

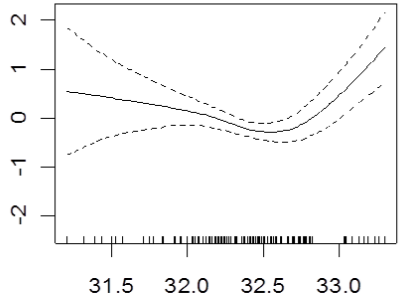

salinity below pycnocline

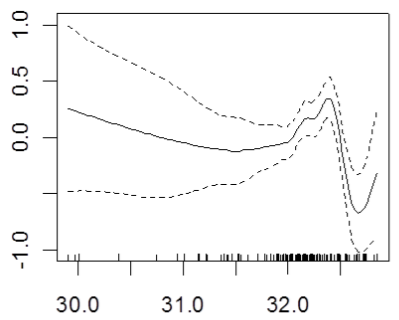

salinity above pycnocline 

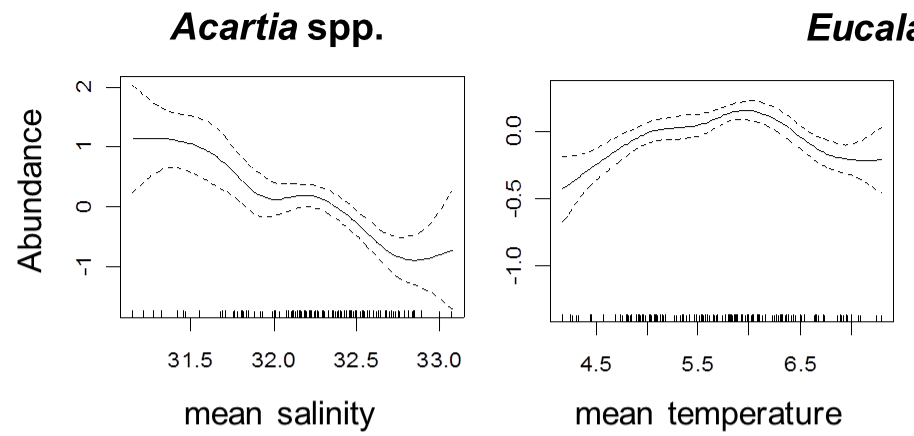

Eucalanus bungii
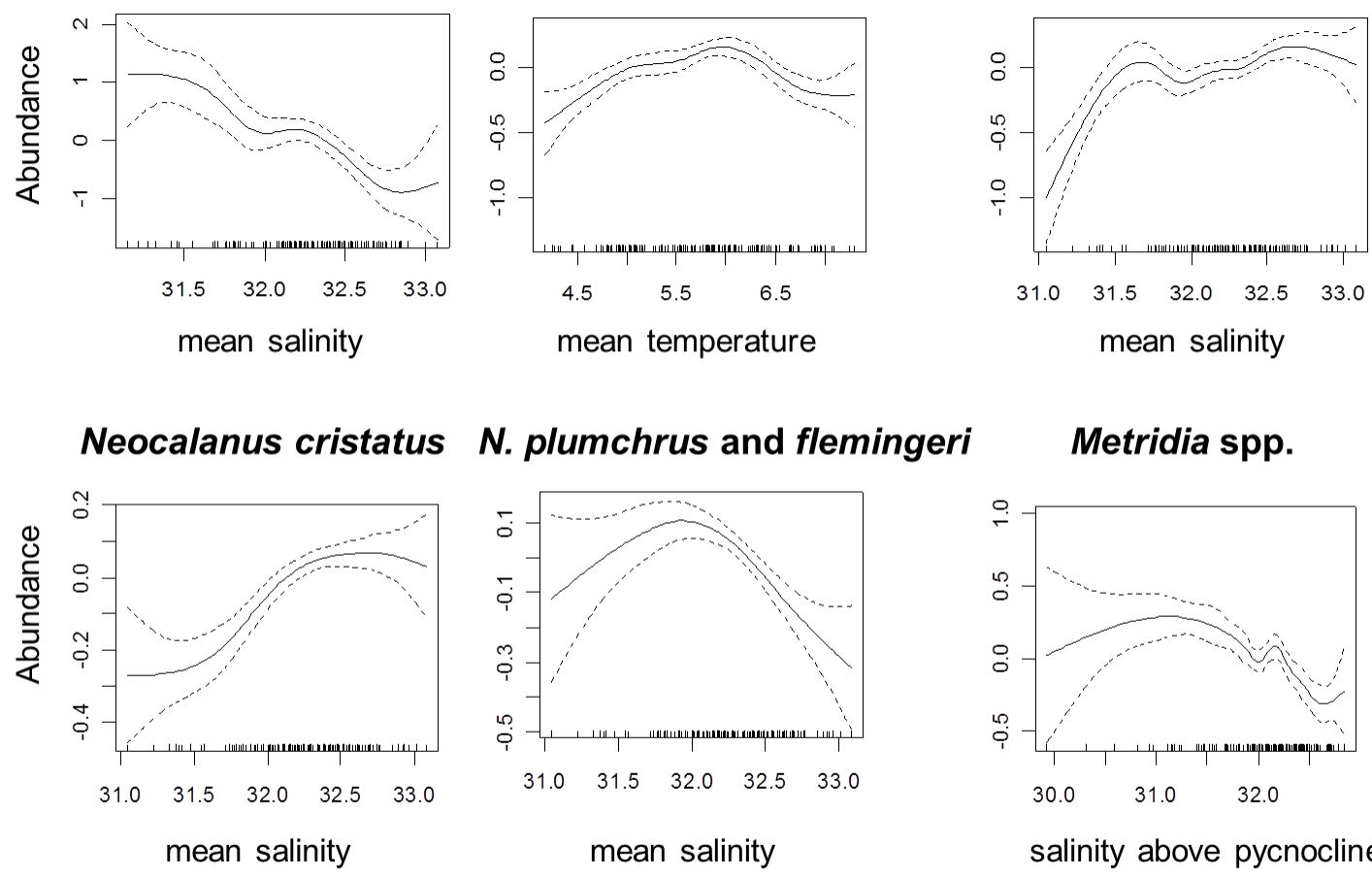

Neocalanus cristatus

Metridia spp.

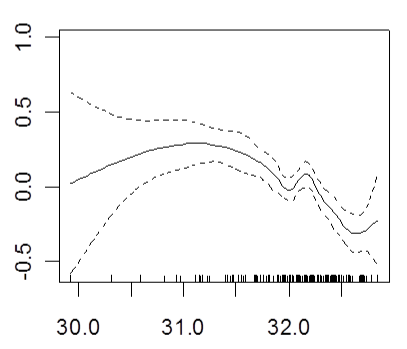

salinity above pycnocline 


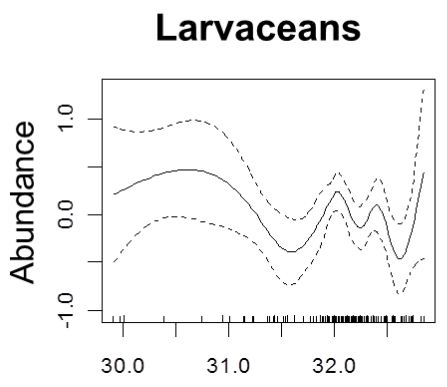

salinity above pycnocline
Thysanoessa spinifera

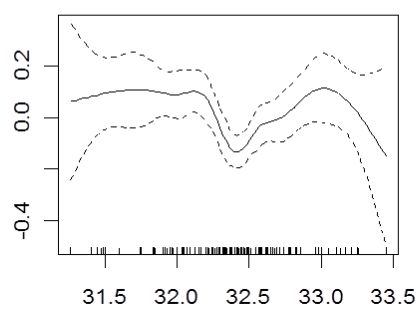

salinity below pycnocline

\section{Euphausia pacifica}

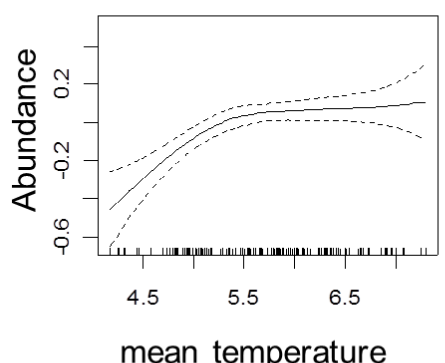

mean temperature

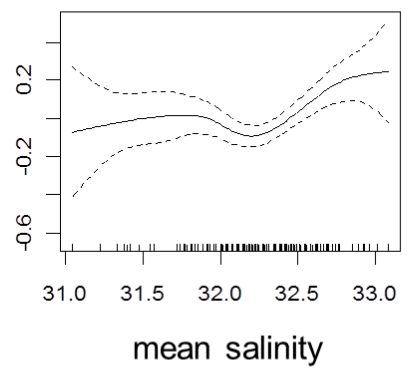

Thysanoessa inermis

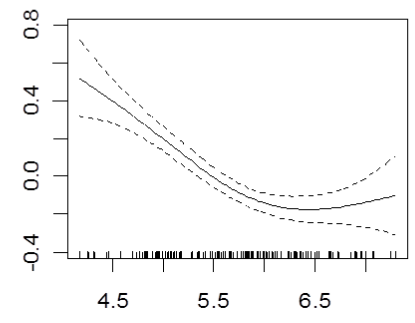

mean temperature

\section{Chaetognatha}

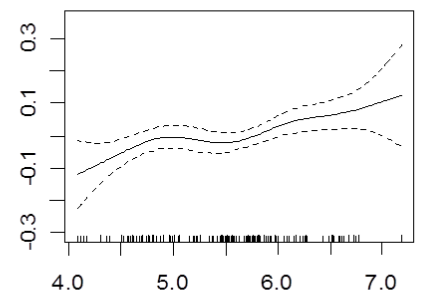

temperature below pycnocline 


\section{Pteropods}
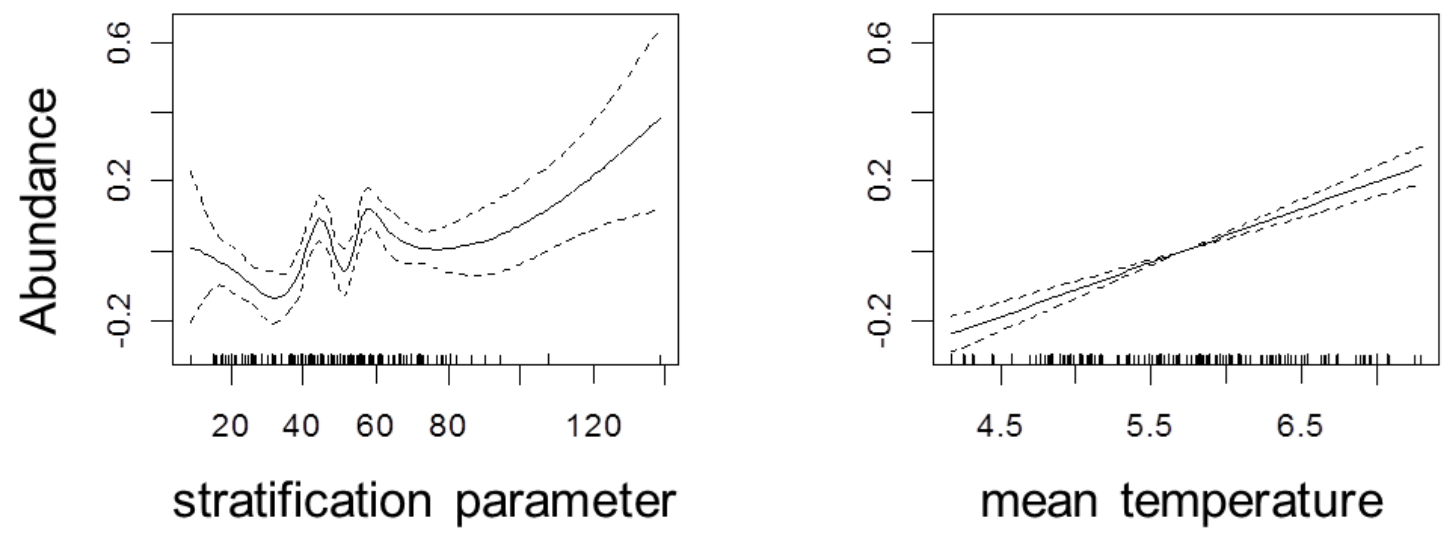


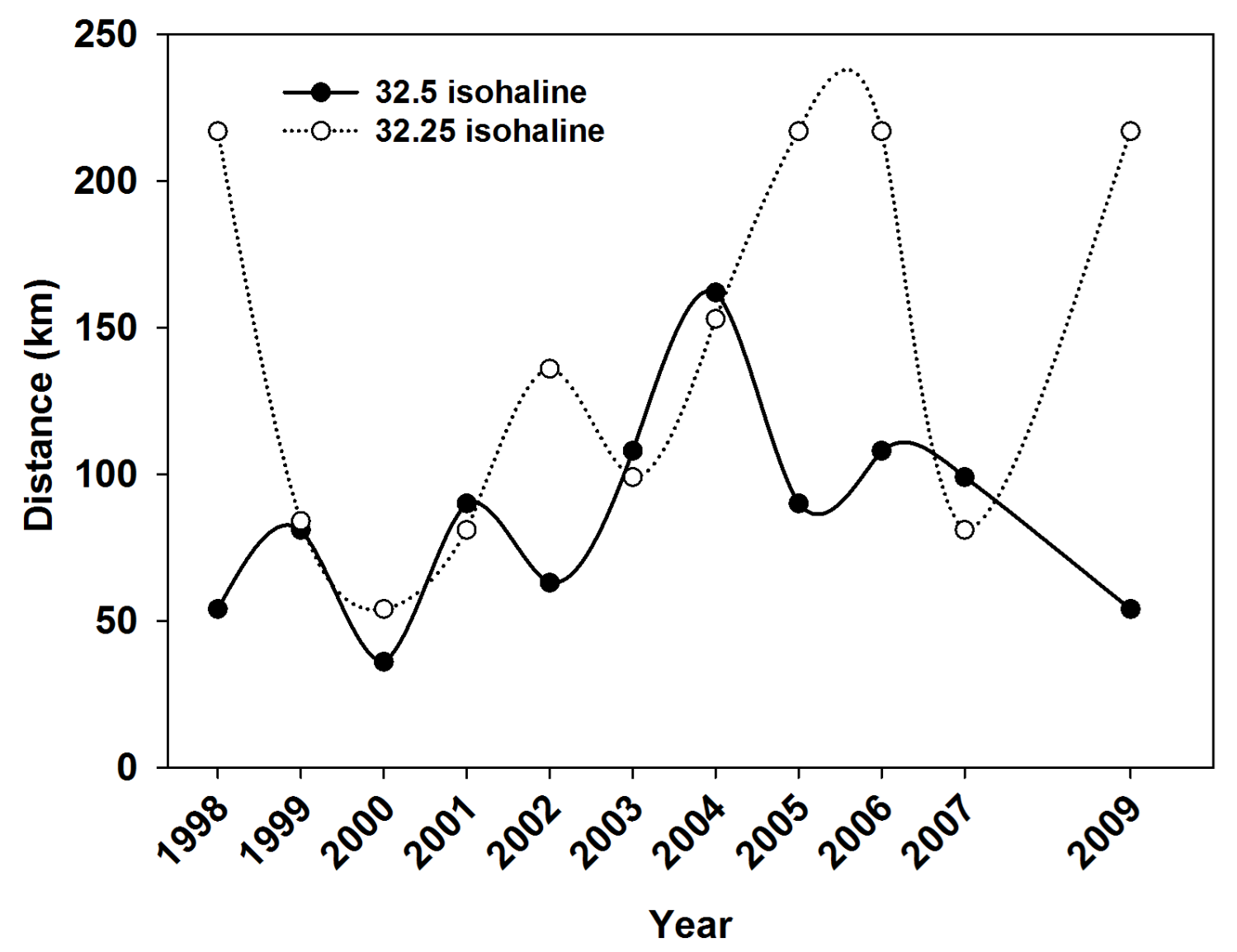




\section{Figure Legends}

Figure 1. Map of the Gulf of Alaska. The flow of the Alaska Coastal Currents and Subarctic Gyre are indicated as are several geographic place names (After Reed and Schumacher, 1986)

Figure 2. Station locations that were sampled in May (1998-2009) in the northern GOA along the Seward line $(220 \mathrm{~km})$; black dots represent stations where zooplankton and physical oceanography data were collected; stars represent stations where only physical oceanography data were collected. Curly brackets indicate the three shelf zones (inner, middle, oceanic). Inset map shows the Seward line location in the northern GOA.

Figure 3. Mean temperature (a) and salinity (b) by year along the Seward line in the northern GOA in May 1998-2009. Above pycnocline (red); below pycnocline (green); upper $100 \mathrm{~m}$ (blue); error bars indicate $95 \%$ confidence intervals

Figure 4. Mean stratification parameter (a) and pycnocline depth (b) by year along the Seward line in the northern GOA in May 1998-2009 in the upper 100 m; error bars indicate $95 \%$ confidence intervals

Figure 5. Mean abundance of zooplankton by year along the Seward line in the northern GOA in May 1998-2009. CalVET tows (a)-(d); MOCNESS tows (e)-(f). Data are power transformed (raised to the power of 0.15 ) to stabilize the variance; error bars are $95 \%$ confidence intervals.

Figure 6. Mean abundance of zooplankton by year along the Seward line in the northern GOA in May 1998-2009. MOCNESS tows (a)-(f). Data are power transformed (raised to the power of 0.15 ) to stabilize the variance; error bars are $95 \%$ confidence intervals. 
Figure 7. Mean abundance of zooplankton by year along the Seward line in the northern GOA in May 1998-2009. MOCNESS tows (a)-(b); CalVET tows (c). Data are power transformed (raised to the power of 0.15 ) to stabilize the variance; error bars are $95 \%$ confidence intervals.

Figure 8. GAM best-fit models for C. marshallae and Pseudocalanus spp., showing fitted relationships and additive effects of significant water mass properties on zooplankton abundance in May along the Seward line in the northern GOA 1998-2009. Dashed lines: upper and lower pointwise twice-standard-error curves, ticks along the $\mathrm{x}$ axis: locations of data points along x-axis. For specific names see Table 3.

Figure 9. GAM best-fit models for Calanoid nauplii and Oithona spp., showing fitted relationships and additive effects of significant water mass properties on zooplankton abundance in May along the Seward line in the northern GOA 1998-2009. Dashed lines: upper and lower pointwise twice-standard-error curves, ticks along the x-axis: locations of data points along x-axis. For specific names see Table 3.

Figure 10. GAM best-fit models for Acartia spp., E. bungii, N. cristatus, Neocalanus spp. and Metridia spp. showing fitted relationships and additive effects of significant water mass properties on zooplankton abundance in May along the Seward line in the northern GOA 1998-2009. Dashed lines: upper and lower pointwise twice-standard-error curves, ticks along the x-axis: locations of data points along x-axis. For specific names see Table 3.

Figure 11. GAM best-fit models for Larvaceans and T. spinifera, T. inermis, E. pacifica, Chaetognatha, showing fitted relationships and additive effects of significant water mass 
properties on zooplankton abundance in May along the Seward line in the northern GOA 1998-2009. Dashed lines: upper and lower pointwise twice-standard-error curves, ticks along the $\mathrm{x}$-axis: locations of data points along $\mathrm{x}$-axis. For specific names see Table 3. Figure 12. GAM best-fit model for Pteropods, showing fitted relationships and additive effects of significant water mass properties on zooplankton abundance in May along the Seward line in the northern GOA 1998-2009. Dashed lines: upper and lower pointwise twice-standard-error curves, ticks along the $\mathrm{x}$-axis: locations of data points along $\mathrm{x}$-axis. For specific names see Table 3.

Figure 13. Farthest distance of 32.25 isohaline from shore at depths $<100 \mathrm{~m}$ (white circles) indicating the extent of neritic waters across the shelf, and closest distance of the 32.50 isohaline to shore at depths $<100 \mathrm{~m}$ (black circles) indicating the extent of oceanic waters across the shelf, by year along the Seward line in the northern GOA in May. 


\section{Tables}

Table 1. Differences in mean water mass properties as identified by multiple comparison Tukey test results: mean salinity (upper $100 \mathrm{~m}$, MSal), mean salinity above the pycnocline (UpSal), mean salinity below the pycnocline (LoSal), mean temperature (upper $100 \mathrm{~m}, \mathrm{MTemp}$ ), mean temperature above the pycnocline (UpTemp), mean temperature below the pycnocline $(\operatorname{LoTemp})\left({ }^{\circ} \mathrm{C}\right)$, pycnocline depth $(\mathrm{PycDep})(\mathrm{m})$, and stratification parameter (StratPar) $\left(\mathrm{J} \mathrm{m}^{-3}\right)$, by year along the Seward line in May 19982009; Significant inter-annual differences are indicated by " $>$ " and " $<$ " at p-value $<0.05$

\begin{tabular}{|c|c|c|c|c|c|c|c|c|c|c|c|}
\hline \multirow[b]{2}{*}{ Variable } & \multicolumn{11}{|c|}{ Year } \\
\hline & 1998 & 1999 & 2000 & 2001 & 2002 & 2003 & 2004 & 2005 & 2006 & 2007 & 2009 \\
\hline MSal & 32.11 & 32.46 & 32.50 & 32.44 & 32.23 & 32.24 & 31.96 & 32.08 & 32.16 & 32.31 & 32.34 \\
\hline $\begin{array}{l}\text { Tukey } \\
\text { test }\end{array}$ & \multicolumn{11}{|c|}{$2004<1999 \approx 2000 \approx 2001$} \\
\hline UpSal & 31.81 & 32.33 & 32.26 & 32.29 & 32.10 & 32.04 & 31.76 & 31.72 & 31.92 & 32.17 & 32.02 \\
\hline $\begin{array}{l}\text { Tukey } \\
\text { test }\end{array}$ & \multicolumn{11}{|c|}{$2005<1999 \approx 2001 ; 2004<1999$} \\
\hline LoSal & 32.30 & 32.63 & 32.61 & 32.63 & 32.42 & 32.29 & 32.06 & 32.16 & 32.27 & 32.36 & 32.40 \\
\hline $\begin{array}{l}\text { Tukey } \\
\text { test }\end{array}$ & \multicolumn{11}{|c|}{$2004<1999 \approx 2000 \approx 2001 ; 2005<2001$} \\
\hline MTemp & 6.70 & 5.59 & 5.95 & 5.589 & 4.92 & 6.74 & 5.74 & 6.19 & 5.91 & 4.97 & 4.69 \\
\hline $\begin{array}{l}\text { Tukey } \\
\text { test }\end{array}$ & \multicolumn{11}{|c|}{$1998 \approx 2003>2005>1999 \approx 2001 \approx 2004>2002 \approx 2007 \approx 2009$} \\
\hline
\end{tabular}

Table 1. Continued

\begin{tabular}{llllllllllll} 
& \multicolumn{10}{c}{ Year } \\
\cline { 2 - 9 } Variable & 1998 & 1999 & 2000 & 2001 & 2002 & 2003 & 2004 & 2005 & 2006 & 2007 & 2009 \\
\hline \hline
\end{tabular}




\begin{tabular}{|c|c|c|c|c|c|c|c|c|c|c|c|}
\hline pTemp & 6.94 & 5.76 & 6.80 & 5.70 & 5.12 & 8.31 & 6.235 & 7.69 & 6.27 & 5.62 & 6.04 \\
\hline $\begin{array}{l}\text { ukey } \\
\text { st }\end{array}$ & \multicolumn{11}{|c|}{$\begin{array}{l}2003 \approx 2005>1998,2000,2001,2002,2003,2004,2006,2007,2009 ; 1998>2001, \\
2002,2003,2004,2006,2007,2009 ; 2000>1999,2001,2002,2007,2009 ; 2004 \\
\approx 2006 \approx 2009>2002,\end{array}$} \\
\hline oTemp & 6.52 & 5.52 & 5.640 & 5.49 & 4.90 & 6.26 & 5.51 & 5.98 & 5.69 & 4.80 & 4.50 \\
\hline $\begin{array}{l}\text { ukey } \\
\text { est }\end{array}$ & \multicolumn{11}{|c|}{$\begin{array}{l}1998 \approx 2003>1999,2000,2001,2002,2004,2005,2006,2007,2009 ; 2005>1999, \\
2001,2002,2004,2007,2009 ; 1999 \approx 2000 \approx 2001 \approx 2004 \approx 2006>2002 \approx 2007 \approx \\
2009\end{array}$} \\
\hline & 41.77 & 53.15 & 31.46 & 55.85 & 57.77 & 25.62 & 40.69 & 17.54 & 30.62 & 33.46 & 18.31 \\
\hline $\begin{array}{l}\text { ukey } \\
\text { st }\end{array}$ & \multicolumn{11}{|c|}{$2005 \approx 2009<1999 \approx 2001 \approx 2002$} \\
\hline StratPar & 59.92 & 37.87 & 60.35 & 39.11 & 36.39 & 58.77 & 42.94 & 69.68 & 43.40 & 26.50 & 59.08 \\
\hline $\begin{array}{l}\text { Tukey } \\
\text { est }\end{array}$ & \multicolumn{11}{|c|}{$\begin{array}{l}2005>1999 \approx 2001 \approx 2002 \approx 2004 \approx 2006 \approx 2007 ; 2000>1999 \approx 2001 \approx 2002 \approx \\
2007 ; \\
1998 \approx 2009>1999 \approx 2002 \approx 2007 ; 2003>2002 \approx 2007\end{array}$} \\
\hline
\end{tabular}


Table 2. Differences in mean zooplankton abundance (number m-3) by year along the Seward line in May 1998-2009; as identified by multiple comparison Tukey test results, significant interannual differences are indicated by " $>$ " and " $<$ " at p-value $<0.05$

\begin{tabular}{|c|c|c|c|c|c|c|c|c|c|c|c|}
\hline \multirow[b]{2}{*}{ Variable } & \multicolumn{11}{|c|}{ Year } \\
\hline & 1998 & 1999 & 2000 & 2001 & 2002 & 2003 & 2004 & 2005 & 2006 & 2007 & 2009 \\
\hline
\end{tabular}

Pseudocalanus spp.

Oithona spp.

Acartia spp.

Metridia spp.

Calanus marshallae

Neocalanus spp.

Neocalanus cristatus

Eucalanus bungii

Calanoid nauplii

Euphausia pacifica
$2000>$ 1999, 2001, 2003, 2007, 2009; 2001 < 1998, 2000, 2002, 2004, 2005, 2006

$2000>1998,1999,2001,2002,2003,2007,2009 ; 2004 \approx 2005 \approx 2006>2009 ; 2001<$ all years

$2005>1998,2007,2009 ; 2006>1998,2007$

$2002>1999$

$2006>1998,1999,2000,2001,2003,2007,2009$;

$2005>1999,2000,2001,2003,2007,2009 ; 2002 \approx 2004>2001$

$1998 \approx 2006>1999,2000,2001,2003,2005,2009 ; 2002>2000,2001,2003$

none

$2006>1998,1999,2002,2003,2007,2009 ; 1998<2000,2001,2004,2005,2006$

$2005>1998,2001,2003,2009 ; 2000 \approx 2004>2001,2003,2009 ; 2001<$ all years

$1999 \approx 2005>2002,2007$ 


\begin{tabular}{|c|c|c|c|c|c|c|c|c|c|c|c|}
\hline \multirow[b]{2}{*}{ Variable } & \multicolumn{11}{|c|}{ Year } \\
\hline & 1998 & 1999 & 2000 & 2001 & 2002 & 2003 & 2004 & 2005 & 2006 & 2007 & 2009 \\
\hline $\begin{array}{l}\text { Thysanoessa } \\
\text { spinifera }\end{array}$ & \multicolumn{11}{|c|}{$2001>1998,2004,2006 ; 2000 \approx 2009>2006$} \\
\hline Pteropoda & \multicolumn{11}{|c|}{$\begin{array}{l}2005>1999,2000,2001,2002,2004,2006,2007,2009 ; 2003>1999,2000,2001,2002,2004,2007, \\
2009 ; 1998 \approx 2006>1999,2000,2001,2002,2007,2009 ; 2000 \approx 2001 \approx 2004>2007\end{array}$} \\
\hline Chaetognatha & \multicolumn{11}{|c|}{$2003>2009$} \\
\hline Larvacea & \multicolumn{11}{|c|}{$2001<2002,2004,2005$} \\
\hline
\end{tabular}


Table 3. Species zooplankton abundance (response variable) and water mass properties (explanatory variables) used in best-fit GAM models; "MTemp" = mean temperature in the upper $100 \mathrm{~m}$; "UpTemp" = mean temperature above the pycnocline; "LoTemp" = mean temperature below the pycnocline; "MSal" = mean salinity in the upper $100 \mathrm{~m}$; "UpSal" = mean salinity above the pycnocline, "LoSal" = mean salinity below the pycnocline; "PycDep" = pycnocline depth; "Stratpar" = stratification parameter; black cells: variable contribution to model significant at $\mathrm{p}<0.05$; gray cells: variable contribution to model insignificant at $\mathrm{p}>0.05$; white cells: variables absent from model; pos: variable effect significant and positive; neg: variable effect significant and negative, blank cells: represent neither positive or negative response please refer to Figures 8-12 for GAM plots

\begin{tabular}{|c|c|c|c|c|c|c|c|c|c|}
\hline \multirow[t]{2}{*}{ Species } & \multicolumn{9}{|c|}{ Water mass properties } \\
\hline & MTemp & UpTemp & LoTemp & MSal & UpSal & LoSal & PycDep & StratPar & $\begin{array}{c}\text { Deviance } \\
\text { Explained } \\
(\%)\end{array}$ \\
\hline C. marshallae & & & & & neg & & & & 74.0 \\
\hline $\begin{array}{l}\text { Pseudocalanus } \\
\text { spp. }\end{array}$ & pos & & & neg & & & & & 67.2 \\
\hline Pteropoda & pos & & & & & & & & 55.7 \\
\hline Oithona spp. & & & & & & & & & 55.0 \\
\hline $\begin{array}{l}\text { Calanoid } \\
\text { nauplii }\end{array}$ & & & & & & & & & 47.1 \\
\hline E. bungii & & & & pos & & & & & 46.5 \\
\hline
\end{tabular}


Table 3. Continued

\begin{tabular}{|c|c|c|c|c|c|c|c|c|c|}
\hline Species & & & & Water & mass pr & operties & & & \\
\hline & MTemp & UpTemp & LoTemp & MSal & UpSal & LoSal & PycDep & StratPar & $\begin{array}{c}\text { Deviance } \\
\text { Explained } \\
(\%)\end{array}$ \\
\hline Chaetagnatha & & & pos & & & & & & 39.7 \\
\hline Metridia spp. & & & & & & & & & 39.3 \\
\hline Acartia spp. & & & & neg & & & & & 36.8 \\
\hline T. inermis & neg & & & & & & & & 34.7 \\
\hline Larvacea & & & & & & & & & 33.9 \\
\hline N. cristatus & & & & pos & & & & & 29.3 \\
\hline E. pacifica & pos & & & & & & & & 28.6 \\
\hline $\begin{array}{l}N . \text { plumchrus } \\
\text { and } N . \\
\text { flemingeri }\end{array}$ & & & & & & & & & 20.2 \\
\hline T. spinifera & & & & & & & & & 20.0 \\
\hline
\end{tabular}

